Federal Reserve Bank of Dallas

Globalization and Monetary Policy Institute

Working Paper No. 191

http://www.dallasfed.org/assets/documents/institute/wpapers/2014/0191.pdf

\title{
Benefits of Foreign Ownership: Evidence from Foreign Direct Investment in China ${ }^{*}$
}

\author{
Jian Wang \\ Federal Reserve Bank of Dallas \\ Xiao Wang \\ University of North Dakota \\ September 2014 \\ Revised: October 2014
}

\begin{abstract}
To examine the effect of foreign direct investment, this paper compares the post-acquisition performance changes of foreign- and domestic-acquired firms in China. Unlike previous studies, we investigate the purified effect of foreign ownership by using domestic-acquired firms as the control group. After controlling for the acquisition effect that exists in domestic acquisitions, we find no evidence that foreign ownership can bring productivity gains to target firms. In contrast, a strong and robust finding is that foreign ownership significantly improves target firms' financial conditions and exports relative to domestic-acquired firms. Foreign acquisition is also found to improve output, employment and wage for target firms. These findings conflict with the conventional view of productivity-driven FDI and highlight the financial channel through which FDI benefits the host countries.
\end{abstract}

JEL codes: F15, F21, F23, F36, F60

\footnotetext{
* Jian Wang, Research Department, Federal Reserve Bank of Dallas, 2200 N. Pearl Street, Dallas, TX 75201. 214-922-6471. jian.wang@dal.frb.org. Xiao Wang, University of North Dakota, Gamble Hall Room 290, 293 Centennial Drive Stop 8098, Grand Forks, ND 58202-8098. 701-777-3351. Xiao.wang@business.und.edu. We thank Sebnem Kalemli-Ozcan, Asli Leblebicioglu, Heiwai Tang, Jianfeng $\mathrm{Yu}$ and seminar participants for helpful comments. The views in this paper are those of the authors and do not necessarily reflect the views of the Federal Reserve Bank of Dallas or the Federal Reserve System.
} 


\section{Introduction}

Conventional wisdom follows that FDI can increase host countries' productivity, both directly by introducing new technologies and indirectly by technology spillovers. Such wisdom is supported by numerous empirical studies documenting the superior performance of FDI-involved firms in the host countries and the technology spillovers from these firms to their domestic counterparts. ${ }^{1}$ FDI is also considered safer than other types of capital inflows and became the favorite form of foreign investment for emerging markets following the financial crises in the 1980s and 1990s. ${ }^{2}$ As a result, many emerging markets provide tax and other incentives to attract FDI, and the past three decades have observed dramatic FDI inflows to these countries.

However, policies designed to promote FDI can be counterproductive if policymakers do not understand the mechanisms through which FDI benefits host countries. The positive correlation between firm productivity and FDI cannot be simply interpreted as a causal relationship. Instead, it may just reflect endogenous FDI decisions: foreign investors choose to acquire or start business with more productive domestic firms. For instance, Fons-Rosen et al. (2013) find that FDI has a very small effect on target firms' productivity in their sample of advanced European economies, after controlling for unobservable factors that influence ex-ante acquisition decisions.

Several recent studies explore other motivations for FDI and their effects on host countries. For instance, Nocke and Yeaple (2007) show that cross-border mergers and acquisitions can be driven by the complementarities between internationally mobile and non-mobile capacities rather than productivity differentials. In this case, foreign acquisitions can involve low-productivity local firms if firms are heterogeneous in their internationally mobile assets (such as productivity) and location-specific assets (such as local distribution capabilities). Blonigen et al. (forthcoming) argue that FDI can be driven by the existing export networks of local firms: exporters with existing export networks are more attractive to FDI if firms have to make (sunk) investment to expand export networks. They find strong empirical support for this argument in French firm-level data of

\footnotetext{
${ }^{1}$ For instance, see Javorcik (2004) for Lithuania, Yasar and Morrison Paul (2007) for Turkey and Keller and Yeaple (2009) for the US, among others. However, Aitken and Harrison (1999) and Haddad and Harrison (1993) find no or even negative evidence for such technology spillovers in Morocco and Venezuela.

${ }^{2}$ For instance, Krugman (2001) and Aguiar and Gopinath (2005) document that FDI is counter-cyclical and also less volatile than portfolio investment.
} 
the manufacturing sector.

Our paper contributes to the above literature by emphasizing the role of financial factors in foreign acquisitions instead of the role of productivity. Although some previous empirical studies question the productivity benefits of FDI to advanced economies, it may still be reasonable to believe the productivity gains for FDI to emerging markets because these countries lag far behind advanced economies in technology. However, we document that even foreign acquisitions in China, an emerging market, do not improve target firms' productivity relative to domestic acquisitions. Furthermore, we find that foreign ownership has a strong and robust role in improving target firms' financial conditions, highlighting the financial advantage of FDI to emerging countries. Our results suggest that even FDI to emerging markets could be mainly driven by financial advantages rather than productivity advantages, questioning the policies that intend to catch up to the technological frontier by providing tax and financial benefits to FDI.

To control for the endogeneity issue, we employ the difference-in-differences method combined with propensity score matching (e.g., Arnold and Javorcik, 2009). However, we depart from the literature by examining purified performance gains from foreign ownership after controlling for gains existing in domestic mergers and acquisitions. Previous studies find that foreign acquisitions can improve the performance of target firms even after taking into account selection bias. For instance, see Arnold and Javorcik (2009) for plant-level evidence for Indonesia and Guadalupe, Kuzmina and Thomas (2012) for a study on manufacturing firms in Spain. However, numerous empirical studies document that domestic mergers and acquisitions are also followed by substantial changes in the performance of target firms (e.g., Maksimovic and Phillips, 2001). In particular, Fons-Rosen et al. (2014) find that even negative changes in foreign ownership are also associated with firm productivity improvements, consistent with productivity improvements coming from a general change in ownership rather than an increase in foreign ownership. Therefore, even though previous studies evidently documented performance gains following foreign acquisitions, it remains unclear whether foreign ownership is crucial for the detected gains. In this paper, we compare the post-acquisition performance changes for foreign- and domestic-acquired firms in China and find no evidence that foreign ownership can improve target firms' productivity relative to domestic 
acquisitions. This finding conflicts with the conventional view of productivity driven FDI. ${ }^{3}$

Next, we document robustly that foreign ownership significantly improved the financial conditions (as measured by the leverage and liquidity ratios) of target firms relative to domestic acquisitions, highlighting the financial benefits of FDI. Most previous studies mainly focus on the direct and spill-over transfers of technology from FDI firms to host countries and the associated effects on host countries' economic growth. FDI firms' advantages of easy credit access have been largely neglected in empirical studies until recently. ${ }^{4}$ FDI firms are less financially constrained than domestic firms due to their access to international financial markets and foreign parent companies for credit. This is particularly true in emerging countries where financial markets are usually underdeveloped and domestic firms face serious financial constraints. For instance, Song, Storesletten and Zilibotti (2011) and Dollar and Wei (2007) show that private firms in China are subject to strong discrimination in obtaining credit from state-owned banks, which inspires us to examine whether foreign acquisitions can improve financial conditions of target firms.

In addition, we comprehensively evaluate firm performance following foreign acquisitions, which includes productivity, financial conditions, exports, capital per worker, the real wage, output, employment and real profits. Combined with our careful distinction between gains from foreign ownership and domestic acquisition, our study offers a comprehensive, balanced and accurate description of the advantages of FDI acquisitions relative to domestic acquisitions. This will become clearer when we give more details of our empirical findings. Although our study uses Chinese data, we believe that the findings are likely to hold in other emerging markets.

Our main dataset is obtained from the firm-level data collected through the Annual Surveys of Industrial Production by the National Bureau of Statistics of China from 2000 to 2007. The dataset contains basic firm information (e.g., firm identification number and registration type) and detailed information about each firm's balance sheet and income statement. We use firms' registration information to identify mergers and acquisitions for both domestic and FDI firms. Every firm

\footnotetext{
${ }^{3}$ Chen (2011) also compares foreign- and domestic-acquired US firms, but her study focuses on the effect of FDI's source of origin on the performance of target firms.

${ }^{4}$ Examples of recent studies on the topic include Manova, Wei and Zhang (forthcoming) and Huang et al. (2008). Krugman (2001) and Aguiar and Gopinath (2005) study FDI due to "fire sale" of domestic firms during financial crises.
} 
in China has a registration type that indicates its main ownership. If a firm's registration type experienced a major change from the previous year, the firm's main ownership must have changed due to a merger or acquisition. If a firm's registration type changes from the categories of domestic firms to those of FDI firms, the firm is selected into the group of foreign acquisitions. On the other hand, if a firm's registration type switches within the categories of domestic firms, we place the firm into the group of domestic acquisitions.

Then we compare the post-acquisition performance changes of these two groups of firms, using the difference-in-differences method combined with propensity score matching. We first pair each foreign-acquired firm with a domestic-acquired firm which has similar pre-acquisition characteristics as the corresponding foreign-acquired firm. Then the post-acquisition performance changes of these two groups of firms are compared using the difference-in-differences method. In this way, we minimize the biases caused by endogenous acquisition decisions.

Several interesting findings stand out. First, we do not find strong evidence that foreign ownership can induce productivity gains for target firms. Foreign-acquired firms experience a positive gain in TFP relative to domestic-acquired firms in the acquisition year. However, the gain becomes statistically insignificant in the next two years. The evidence of productivity gain becomes even weaker when we use other measures of productivity such as output per employee. In contrast, if we compare foreign-acquired firms with domestic firms that experienced no change in their ownership, we find significant TFP gains for foreign-acquired firms in both the acquisition year and the subsequent years. These findings suggest that FDI acquisitions in China during our sample period do not perform differently from domestic acquisitions in improving target firms' productivity even though both types of acquisitions induce TFP gains relative to firms without changes in ownership.

Second, foreign ownership significantly improved the financial conditions (as measured by the leverage and liquidity ratios) of target firms relative to domestic acquisitions. Foreign-acquired firms' leverage ratio (total liabilities divided by total assets) ${ }^{5}$ declined significantly relative to that of domestic-acquired firms. In contrast, the liquidity ratio (the difference of current assets and liabilities divided by total assets) of foreign-acquired firms increased significantly relative to

\footnotetext{
${ }^{5}$ This measure of the leverage ratio is employed in studies such as Ahn, Denis and Denis (2006). Our results are qualitatively robust to using other leverage ratio measures such as short-term debt divided by current assets.
} 
domestic-acquired firms. These findings are in sharp contrast with the results of TFP. They show that following acquisitions, foreign-acquired firms rely less on external short-term debt and more on internal capital than domestic-acquired firms, highlighting the advantages of foreign ownership in relaxing credit constraints faced by target firms. All of our results of financial conditions are significant at the $1 \%$ level, except for one case which is significant at the $5 \%$ level. The improvements of financial conditions are also quantitatively meaningful. For instance, the liquidity ratio of foreignacquired firms increased over 4 percentage points two years following the acquisition relative to domestic-acquired firms, which is a substantial increase relative to its pre-acquisition mean of $11 \%$.

We also find that FDI improves target firms' exports, supporting the financial channel of FDI in promoting international trade. Manova, Wei and Zhang (forthcoming) find that FDI firms in China have better export performance than domestic firms, and this finding is more pronounced in financially more vulnerable sectors. Their findings suggest that FDI can mitigate financial constraints of firms in the host countries and hence promote exports and economic growth. However, they do not examine the effect of FDI on firm productivity. Our results complement Manova, Wei and Zhang's (forthcoming) findings and show that such a channel remains at work even after we exclude the effect of domestic acquisition. In addition, we check the robustness of the findings across different sources of origin for FDI and the pre-acquisition export status of target firms. ${ }^{6}$

Foreign ownership is also found to increase output, employment and wages of target firms relative to domestic-acquired firms. This may be because that the improvements of financial conditions can help firms increase sales and market shares relative to their rivals, as suggested in previous empirical studies. All in all, our empirical results suggest the following channels through which foreign ownership benefits the host countries: foreign ownership can strongly ease target firms' financial constraints and promote their participation in export activities, resulting in increases in output, employment and labor incomes. However, we do not find strong evidence that foreign ownership increases firm productivity.

Our paper is related to several studies using China's firm-level data. Huang et al. (2008)

\footnotetext{
${ }^{6}$ Beside FDI, monetary policy may also influence international trade through financial channels. For instance, Ju, Lin and Wei (2014) recently document that changes in monetary policy can affect exports through their effect on financial constraints of trade sectors, on top of the effect through the real exchange rate and aggregate demand.
} 
show that firms with greater financial constraints are more likely to be acquired by foreigners, using firm-level data in the garment industry of China. While their results support that target firms' financial constraints are an important pre-acquisition factor for endogenous FDI decisions, our findings focus on the causal effect of FDI on target firms' post-acquisition financial conditions. Our study also covers broader industries than theirs. Manova and Zhang (2009) document several stylized facts in China's firm-level trade data. Among these facts, the trading activity of FDI firms in China is systematically different from that of domestic firms. Relative to domestic firms, FDI firms trade more and import more products from more source countries, but export fewer products to fewer destinations. While their study documents the difference in exporting behaviors between domestic and FDI firms, we identify the causal effect of FDI on target firms' exports following the acquisition.

The remainder of the paper is arranged as follows. Section 2 describes our econometric strategy and related studies. Section 3 introduces the data, the way we identify acquisitions from firms' registration information and the method we use to calculate firm-level TFP. Section 4 presents our empirical results, and section 5 concludes.

\section{Econometric Strategy and Related Literature}

The primary goal of our paper is to study whether FDI can improve acquired firms' performance. A simple least-squares estimation in this case is unable to disentangle correlation and causality since the acquisition decision is endogenously made by foreign companies. The above endogeneity issue can be mitigated by employing the difference-in-differences method. Under this method, the firms acquired by foreigners (treatment group) are compared to the firms that are not acquired by foreigners (control group). If the average performance improvement of the treatment group differs systematically from that of the control group following the acquisition, it provides evidence that the foreign acquisition may have caused such performance improvement.

Let $Y$ be a measure of firm performance that is of interest (e.g., productivity, wage, employ- 
ment). We are interested in

$$
\beta \equiv\left[E Y^{a}(1)-E Y^{b}(1)\right]-\left[E Y^{a}(0)-E Y^{b}(0)\right]
$$

where $E Y^{m}(W)$ is the expected value of $Y$ for group $W$ (treatment group if $W=1$; control group if $W=0)$ before $(m=b)$ or after $(m=a)$ the acquisition. For instance, $E Y^{a}(1)$ and $E Y^{b}(1)$ are the expected values of $Y$ for the treatment group after and before the treatment, respectively. $\beta$ is the average change of $Y$ in the treatment group after the treatment relative to that in the control group. This method removes biases in after-treatment comparison between the treatment and control groups that result from permanent differences between these groups (e.g., higher average productivity of the treatment group than that of the control group).

However, there are two potential pitfalls for the above method. First, the choice of control group is a crucial issue for studying the effect of foreign acquisitions on target firms' performance. One may want to use all firms that are not acquired by foreigners as the control group. In this case, the underlying question is whether a firm performs better after being acquired by foreign firms relative to a firm that is not acquired by foreigners. However, there are two types of domestic firms in the control group. Some domestic firms experienced no change in their ownership and others were acquired by their domestic peers. In the case of no change in ownership, even if foreignacquired firms on average outperform the firms in the control group, it is still not clear whether the performance improvement is caused by the foreign ownership or due to an acquisition in general. The target firms would probably have experienced similar performance improvement had they been acquired by domestic firms. Indeed, there is a large literature documenting the productivity and other gains of target firms from acquisitions. Therefore, we argue that an appropriate control group should only include the firms that are acquired by domestic firms. ${ }^{7}$

Second, the difference-in-differences method is still vulnerable to any time-varying bias induced by the foreign firms' non-random selection of target firms. This issue is addressed in the literature

\footnotetext{
${ }^{7}$ Arnold and Javorcik (2009) examine, as a robustness check, the effects of foreign acquisitions versus domestic acquisitions using privatization cases in their data. However, they only have 80 or less observations in their data and could not control for factors such as the industrial and acquisition year effects due to data limitations. Our data contain information that allows us to investigate this issue more thoroughly.
} 
by combining the difference-in-differences method with some matching technique that creates a comparison group with similar pre-acquisition characteristics as the treatment group. In this way, the comparison is restricted to the differences within carefully selected pairs of firms/plants that have similar observable pre-acquisition characteristics. For instance, Arnold and Javorcik (2009) and Chen (2011) estimated the probability of firms/plants being acquired by foreigners using a probit model, and the predicted probability (propensity score) forms the basis of matching the treatment and control firms/plants. In this paper, we combine the difference-in-differences method with the propensity score matching method in Abadie and Imbens (2009). Compared to previous studies, Abadie and Imbens (2009) take into account the fact that the propensity scores are random variables and are estimated from the data (instead of being constants), and they derive the adjustment to the large sample variance of the estimated treatment effects.

Formally, let $W_{i} \in\{0,1\}$ be the treatment indicator for acquired firm $i$. $W_{i}=1$ if firm $i$ is acquired by foreigners and $W_{i}=0$ if it is acquired by a domestic firm. We focus on the difference in firm performance before $(b)$ and after $(a)$ acquisition, $Y_{i}^{a}-Y_{i}^{b}$. Ideally, if we have the observation that firm $i$ is acquired by a foreign firm, as well as the observation that the same firm $i$ is acquired by a domestic firm while keeping everything else constant:

$$
Y_{i}^{a}-Y_{i}^{b}=\left\{\begin{array}{cc}
Y_{i}^{a}(1)-Y_{i}^{b}(1), & \text { for } W_{i}=1 \\
Y_{i}^{a}(0)-Y_{i}^{b}(0), & \text { for } W_{i}=0
\end{array}\right.
$$

then the average treatment effect for these firms can be measured by:

$$
\beta=E\left[\left(Y_{i}^{a}(1)-Y_{i}^{b}(1)\right)-\left(Y_{i}^{a}(0)-Y_{i}^{b}(0)\right)\right]
$$

However, we observe in the data that firm $i$ is acquired by either foreigners or domestic agents, but not both. Therefore, it is impossible to compare the same firm's performance after a foreign acquisition with its performance following a domestic acquisition. Instead, we have to find a counterfactual estimate of firm $i$ 's missing observation and compare it with the observed performance of firm $i$. For instance, if firm $i$ is acquired by foreigners, we use a domestic-acquired firm $j$ as firm 
$i$ 's counterfactual estimate. In this case, we would like to have the pre-acquisition characteristics of firms $i$ and $j$ be as similar as possible. To achieve this goal, the following matching method is employed to pair foreign- and domestic-acquired firms.

Let $X$ be a $k$-dimension vector of covariates that are used in matching. If the chance of being acquired by a foreign or domestic firm is independent of the target firm's performance after controlling for $X,{ }^{8}$ the average treatment effect of the treated group can be calculated from:

$$
\beta=E\left[E\left[Y^{a}-Y^{b} \mid W=1, X=x\right]-E\left[Y^{a}-Y^{b} \mid W=0, X=x\right] \mid W=1\right] .
$$

To estimate $\beta$, we first use the probability of being acquired by a foreign firm conditional on $X$, $p(X)=\operatorname{Pr}(W=1 \mid X)$, as the propensity score to match foreign-acquired and domestic-acquired firms, and $p(X)$ is estimated from a logit model. We will describe the variables in $X$ when presenting our results for the logit model in section 3.3. Next, we find our control group firms by applying the nearest neighbor matching method, which matches foreign-acquired firms with domestic-acquired firms with the closest propensity scores. With the treatment group and control group firms, we can estimate $\beta$ from:

$$
\hat{\beta}=\frac{1}{N}\left[\sum_{i=1}^{N}\left(Y_{i}^{a}-Y_{i}^{b}\right)-\sum_{j=1}^{N}\left(Y_{j}^{a}-Y_{j}^{b}\right)\right],
$$

where $i$ and $j$ are indexes for the treatment group and the control group, respectively, and $N$ is the number of matched firm pairs.

\section{Data}

Our main dataset contains firm-level data that are collected through the Annual Surveys of Industrial Production by the National Bureau of Statistics of China. The raw dataset covers all state-owned manufacturing firms and private manufacturing firms with sales greater than 5 million

\footnotetext{
${ }^{8}$ This is referred to as the conditional independence assumption (CIA) or conditional unconfoundedness in the literature.
} 
RMB (approximately 600,000 dollars at the exchange rate of 2000) from 2000 to 2007 . We lose the observations in 2000 because we need information about changes in registration type to identify acquisitions. In addition, we have to end our sample in 2005 because we want to study the firms' performance in the following two years after the acquisition. Therefore, our consolidated dataset for empirical exercises covers the period between 2001 and 2005. On average, there are over 125,000 firm-level observations each year from 2000 to 2007.

The firm-level data include some basic firm information such as firm identification number, registration type, start year, operating status and total employment. We use the changes in registration type to identify firm acquisitions, which we will describe shortly. Our dataset also contains detailed information about each firm's balance sheet and income statement. The balance sheet data report detailed information about assets and liabilities such as total assets, fixed assets, current assets, long-run investment, total liabilities, total equities and capital. Capital information includes disaggregate-level information about the ownership of capital (e.g., state, collective, corporate, special districts and foreign). So we can use such information as a cross-check on firms' ownership. The data on income statement include each firm's total sales, total industry production, value added, export volume, income from main product, cost from main product, financing cost, interest cost, tax, wages, employee benefits, total intermediate inputs, total profits, etc. The above data are used to calculate TFP of each firm, and we will describe the method of calculating firm TFP later in this section.

Other variables used in our paper include the real wage, real capital per worker, export share, leverage ratio and liquidity ratio. The real wage is calculated by deflating the nominal wage (total nominal wage divided by the total number of employees) by CPI, and this variable reflects the real labor incomes. Real capital per worker is obtained by dividing nominal capital per worker by industry-level PPI, which captures capital intensity of firms. Export share is measured by the ratio of exports to total sales.

Following the literature, the leverage ratio is defined as the ratio of total liabilities to total assets, though our results are qualitatively robust to using other leverage ratio measures such as 
short-term debt divided by current assets. ${ }^{9}$ A higher leverage ratio indicates that the firms depend more on external financing to cover operational costs. These firms usually have more difficulties raising funds in the future and therefore are more financially constrained. Following Greenaway, Guariglia and Kneller (2007), the liquidity ratio is measured by:

$$
\text { Liquidity ratio }=\frac{\text { Current assets }- \text { Current liabilities }}{\text { Total assets }}
$$

Current assets and liabilities are firms' short-term assets and liabilities. A higher liquidity ratio indicates that firms have more liquid assets to cope with potential external financial disruptions, and therefore are less vulnerable to financial shocks and less financially constrained. Table 1 reports the summary statistics of the variables used in our paper.

\subsection{Mapping Registration Changes to Acquisitions}

Every firm in China has a registration type that indicates its main ownership. We classify these registration types into four categories: state or collectively owned domestic firms, privately owned domestic firms, mixed domestic firms and FDI firms. State-owned and collectively owned firms are classified into one category because they usually contain government or semi-government ownership. The first three categories include all domestic firms, while the last one contains foreign-owned firms and joint ventures. The mappings of individual firms' registration types into these four categories are described in the appendix. If a firm's registration type changed from one category to another, its main ownership must have changed due to mergers and acquisitions. Firms are classified as domestic acquired if their registration types changed within the first three categories, while firms are classified as foreign acquired if their registration types changed from one of the three domestic categories into the category of FDI firms.

Table 2 shows the total number of firms and the number of different types of acquisitions in each year in our raw dataset. In each year, around 4,000 acquisitions are domestic ones and about 500 domestic firms are acquired by foreigners. As we mentioned, foreign-acquired domestic firms

\footnotetext{
${ }^{9}$ The ratio of short-term debt to current assets is used as a measure of the leverage ratio in Greenaway et al. (2007) and following studies.
} 
are matched with their domestic-acquired counterparts. Then we compare the performance of these two groups of acquisitions to investigate the effect of foreign ownership on firm performance. ${ }^{10}$

Here we need to acknowledge one potential issue of using our registration categories to identify domestic and foreign acquisitions. In this paper, we group several registration types into one category. For instance, the category of privately owned domestic firms includes the following four registration types: sole proprietorship, partnership, private limited liability corporations and private company limited by shares. The changes of registration types within a category may also be due to mergers and acquisitions, which will not be captured in our benchmark results. In other words, we only consider a subset of all mergers and acquisitions in our data. However, using all registration type changes in the data has its own problem. Registration type changes may simply reflect changes in a firm's legal status or business expansion, instead of changes in ownership. For instance, many registration type changes within a category are not accompanied by significant changes in the firms' capital, indicating no major change in their ownerships. In contrast, the changes of registration types among categories that are used in our paper are all associated with major changes in firms' capital structure, indicating ownership changes due to mergers and acquisitions. In addition, we believe that acquisitions of domestic firms by foreigners are substantial changes in the firms' ownership and such changes are more comparable to acquisitions across different categories rather than within each category. We will also show later in a robustness check that our main findings hold up well when all registration type changes are considered as ownership changes.

\section{$3.2 \quad$ Firm TFP}

Firm TFP is calculated following Ackerberg, Caves and Frazer (2006) and re-scaled around the industry TFP mean and divided by the industry TFP standard deviation. ${ }^{11}$

\footnotetext{
${ }^{10}$ Our results do not change qualitatively if we exclude the firms that change their registration types multiple times during our sample period. Results are available upon request.

${ }^{11}$ See De Loecker and Warzynski (2012) for an example of using this method.
} 
Consider the following production function for firm $i$ in a given industry:

$$
y_{i t}=\beta_{k} k_{i t}+\beta_{l} l_{i t}+\omega_{i t}+\varepsilon_{i t}
$$

where $y_{i t}$ is the $\log$ of output, $k_{i t}$ is the $\log$ of capital input and $l_{i t}$ is the log of labor input. ${ }^{12}$ These variables are observable to the econometrician. $\omega_{i t}$ is the TFP shock that is observable to the firm, but unobservable to the econometrician. $\varepsilon_{i t}$ is the error term that is not predictable to the firm. OLS cannot be used to estimate equation (1) if the choice of $k_{i t}$ or $l_{i t}$ is a function of $\omega_{i t}$, which is likely to be true in reality. We follow Ackerberg, Caves and Frazer (2006) to solve this endogeneity issue.

First assume $\omega_{i t}$ follows an exogenous first-order Markov process:

$$
p\left(\omega_{i t+1} \mid I_{t}\right)=p\left(\omega_{i t+1} \mid \omega_{t}\right)
$$

where $I_{t}$ is firm $i$ 's information set at time $t$. It is further assumed that the firm's intermediate input is determined after its choices of labor and capital input and the realization of $\omega_{i t}$. Suppose the demand for intermediate input takes the form of:

$$
m_{i t}=f_{t}\left(\omega_{i t}, k_{i t}, l_{i t}\right)
$$

It is assumed that $f_{t}$ is monotonic in $\omega_{i t}$. Therefore, we can invert the input demand function to get $\omega_{i t}$ :

$$
\omega_{i t}=f_{t}^{-1}\left(m_{i t}, k_{i t}, l_{i t}\right) .
$$

\footnotetext{
${ }^{12}$ In our data, $y_{i t}$ and $k_{i t}$ are measured by log value-added output and log fixed assets, respectively. Both variables are deflated by 2 -digit industrial level PPI. $l_{i t}$ is measured by the logarithm of the number of employees.
} 
Substituting equation (4) to (1), we have:

$$
\begin{aligned}
y_{i t} & =\beta_{k} k_{i t}+\beta_{l} l_{i t}+f_{t}^{-1}\left(m_{i t}, k_{i t}, l_{i t}\right)+\varepsilon_{i t} \\
& =\Phi_{t}\left(m_{i t}, k_{i t}, l_{i t}\right)+\varepsilon_{i t},
\end{aligned}
$$

where $\Phi_{t}\left(m_{i t}, k_{i t}, l_{i t}\right) \equiv \beta_{k} k_{i t}+\beta_{l} l_{i t}+f_{t}^{-1}\left(m_{i t}, k_{i t}, l_{i t}\right)$. We employ a second-order polynomial approximation for $f_{t}^{-1}\left(m_{i t}, k_{i t}, l_{i t}\right)$. So the estimate of $\Phi_{t}\left(m_{i t}, k_{i t}, l_{i t}\right), \widehat{\Phi}_{t}\left(m_{i t}, k_{i t}, l_{i t}\right)$, is obtained by regressing $y_{i t}$ on $m_{i t}, k_{i t}, l_{i t}$ and their second-order terms. ${ }^{13}$

Next, two moment conditions are employed to estimate $\beta_{k}$ and $\beta_{l}$ :

$$
E\left[\xi_{i t}\left(\begin{array}{c}
k_{i t} \\
l_{i t}
\end{array}\right)\right]=0
$$

where $\xi_{i t}=\omega_{i t}-E\left[\omega_{i t} \mid \omega_{i t-1}\right]$ is the innovation in $\omega_{i t}$. These two moment conditions are from the assumption that capital and labor inputs are chosen before the realization of $\omega_{i t}$.

To be specific, for given $\widehat{\beta}_{k}$ and $\widehat{\beta}_{l}$, we have:

$$
\widehat{\omega}_{i t}=\widehat{\Phi}_{t}\left(m_{i t}, k_{i t}, l_{i t}\right)-\widehat{\beta}_{k} k_{i t}-\widehat{\beta}_{l} l_{i t} .
$$

Then $\widehat{\xi}_{i t}$ is obtained with a third-order polynomial approximation by regressing $\widehat{\omega}_{i t}$ on $\widehat{\omega}_{i t-1}, \widehat{\omega}_{i t-1}^{2}$ and $\widehat{\omega}_{i t-1}^{3}$. In the estimation, $\widehat{\beta}_{k}$ and $\widehat{\beta}_{l}$ are selected to minimize the sample analogue to the moment conditions in equation (5):

$$
\min _{\widehat{\beta}_{k}, \widehat{\beta}_{l}} \Lambda=\frac{1}{T} \frac{1}{N} \sum_{t=1}^{T} \sum_{i=1}^{N} \widehat{\xi}_{i t}\left(\widehat{\beta}_{k}, \widehat{\beta}_{l}\right)\left(\begin{array}{c}
k_{i t} \\
l_{i t}
\end{array}\right)
$$

where $T$ is the number of sample periods and $N$ is the number of firms in the industry.

In our exercise, we first group firms according to China's 2-digit industry code. For each industry, we follow the above procedure to estimate firms' TFP during the period 2000-2007 ( $T=8)$.

\footnotetext{
${ }^{13}$ Cross terms of these variables are also included in the regression.
} 
In this way, we allow $\beta_{k}$ and $\beta_{l}$ to vary across different industries, but to remain constant over time.

In our estimation, $k_{i t}$ is measured by the fixed assets reported in a firm's balance sheet, $l_{i t}$ is measured by the total number of employees and $m_{i t}$ is measured by the intermediate inputs reported in the firm's income statement. Both fixed assets and intermediate inputs are deflated by industry-level PPI obtained from the China Statistical Yearbook.

Given the estimated $\widehat{\beta}_{k}$ and $\widehat{\beta}_{l}$ from equation (7), we can calculate firm $i$ 's TFP in year $t, \widehat{\omega}_{i t}$, from equation (6). Then $\widehat{\omega}_{i t}$ is normalized around the industrial mean:

$$
\widetilde{\omega}_{i t}=\frac{\widehat{\omega}_{i t}-\mu_{t}}{\sigma_{t}}
$$

where $\mu_{t}$ is the industrial mean of $\widehat{\omega}_{i t}$ and $\sigma_{t}$ is the standard deviation of $\widehat{\omega}_{i t}$. $\widetilde{\omega}_{i t}$ is our final measure of firm $i$ 's TFP in all our empirical exercises.

\subsection{Matching Domestic and Foreign Acquisitions}

To match domestic- and foreign-acquired firms, the following variables are used as regressors in the logit model: firm TFP, employment, the real wage, firm age, the real capital per worker, exporting status, a dummy for state-owned or collectively owned enterprises, the leverage ratio and the liquidity ratio. Blonigen et al. (forthcoming) find that foreign firms are attracted to acquire domestic firms that had high productivity level but were hit by a negative productivity shock. To address this issue, we also include the growth rate of productivity in the pre-acquisition year as an independent variable in a robustness check. Our main findings do not change qualitatively. All variables except firm age are measured in the pre-acquisition year. Among these variables, productivity, employment, the real wage and the real capital per worker are in logs. Dummy variables for the acquisition year and industry (2-digit level) are also added to control for their fixed effects. ${ }^{14}$ The exporting status is measured by a dummy variable indicating whether the firm

\footnotetext{
${ }^{14}$ An alternative method used in the literature for controlling for the acquisition year and industry fixed effects is to first match the treatment and control groups in the same acquisition year and industry and then average the treatment effects across acquisition years/industries. We do not follow this practice because Abadie and Imbens (2008) prove that the bootstrapped standard errors in this method are inconsistent. We check the robustness of our results to the exact match for acquisition year and industry by employing the nonparametric nearest neighbor matching method in Abadie and Imbens (2008) and the results are reported in the appendix (Table A.12).
} 
is an exporter in the year before acquisition or not. Most variables are employed by following Arnold and Javorcik (2009). A dummy is added in our model for state or collectively owned firms because these firms are usually subject to more restrictions on foreign acquisitions. We also include financial condition variables (the leverage ratio and the liquidity ratio) in the estimation to control for the pre-acquisition differences in financial conditions among the treatment and control groups. Since one of our major findings is on the effects of foreign acquisitions on target firms' financial conditions, it is crucial to take into account the differences in financial conditions prior to acquisitions.

Table 3 reports the estimation results of the logit model. All coefficient estimates, except for firm productivity and the leverage ratio, are statistically different from zero at the $1 \%$ level. Firm productivity and the leverage ratio are statistically significant at the $10 \%$ and $5 \%$ levels, respectively. The coefficient estimates suggest that a high level of productivity, employment, the real wage and the real capital per worker can significantly increase a firm's probability of being acquired by foreigners, indicating that FDI targets more productive firms.

Figure 1 shows the average TFP for the foreign and domestic-acquired firms, respectively, from two years prior to the acquisition through two years after the acquisition. Since firm TFP is normalized around the industrial mean (at the 2-digit level), positive TFP values in Figure 1 indicate that both domestic- and foreign-acquired firms are more productive than the average firm in the same industry. In addition, both types of firms exhibit similar TFP decreases relative to the industrial average level prior to the acquisition. These facts are consistent with the "cherrypicking" story studied in Blonigen et al. (forthcoming): investors are more attracted to firms that had above-average productivity, but were hit by a negative productivity shock. Since our treatment and control groups display similar decline in TFP prior to the acquisition, our results of FDI's effect on firm productivity are unlikely to be affected by the "cherry-pricking" behavior of foreign investors.

Being an exporter before the acquisition also significantly increases a firm's chance of being acquired by foreigners. This might be due to two reasons. First, exporters are usually also more productive. Second, FDI may be attracted to firms with existing export networks as in Blonigen 
et al. (forthcoming).

Firm age and government ownership are found to decrease the probability of being acquired by foreigners. Foreign firms seem to also prefer domestic firms with less constrained financial conditions: the leverage ratio decreases a firm's probability of being acquired by foreigners, while the liquidity ratio increases the probability. Since we are interested in the changes in financial conditions following the acquisition, it is important for us to control for the pre-acquisition differences in the leverage ratio and the liquidity ratio to make sure that our findings are not due to foreign firms preferring to acquire domestic firms with better financial conditions.

For each foreign-acquired firm, we choose one domestic-acquired firm whose fitted value in the logit model is the most similar to that of the foreign-acquired firm. We would like the matched foreign-acquired firms and domestic-acquired firms to have pre-acquisition conditions that are as similar as possible. Table 4 presents the results for the balance tests of matching covariates. The second and third columns report, respectively, the means of covariates for foreign-acquired firms and the means for the corresponding domestic-acquired firms that are matched to foreign-acquired firms based on the estimated logit model. Column four displays the difference (in percentage) between two group means (treatment group minus control group). The means of all covariates are very similar between the treatment group and the control group: the differences are less than $3 \%$ in most cases. ${ }^{15}$ The t-tests indicate that the differences in the means of the treatment group and the control group are not statistically different from zero at the conventional significant levels. These results suggest that the foreign-acquired firms and the matched domestic-acquired firms have very similar pre-acquisition characteristics. Therefore, the post-acquisition performance differences are more likely due to foreign ownership rather than endogenous selection biases.

\section{Empirical Results}

As a first pass, we run simple OLS regressions with our data before presenting the results for the difference-in-differences method combined with propensity score matching. In the benchmark difference-in-differences method, we only include the domestic-acquired firms that are paired with

\footnotetext{
${ }^{15}$ Two exceptions are the real wage $(4.2 \%)$ and the dummy variable for state/collectively owned $(3.2 \%)$.
} 
foreign-acquired firms in our sample. In other words, this method gives zero weight to unpaired domestic-acquired firms. In the simple OLS regressions, all domestic-acquired firms are used and can help us check if our results are robust when all domestic-acquired firms in the data are treated equally.

The dependent variable in the simple OLS regressions is the change in firm performance following the acquisition. Independent variables include a dummy variable indicating foreign acquisitions and a location dummy (provinces of target firms). ${ }^{16}$ We also include the independent variables of the logit model in our OLS regressions to control for pre-acquisition differences across firms. We run six regressions in total and the dependent variables in these regressions are three measures of postacquisition changes in productivity (TFP, gross output per employee and value-added output per employee), the leverage ratio, the liquidity ratio and the export share, respectively.

Table 5 summarizes these six regressions, and more details are reported in the appendix. The first column shows the dependent variable in each regression, and each row presents the estimation results for the foreign acquisition dummy. Besides coefficient estimates, robust standard errors clustered by province, year and industry and the corresponding p-values are also displayed in the table. In the first row, the change in productivity as measured by TFP is used as the dependent variable. The coefficient estimate of the foreign acquisition dummy is statistically significant in only one out of three cases (two years after) at the $10 \%$ level, indicating no strong evidence that foreign acquisitions can improve target firms' productivity. Evidence based on other measures of productivity (gross output per employee and value-added output per employee) is even weaker. For instance, when productivity is measured by value-added output per employee, the coefficient estimates are not statistically significant in all three years we consider.

In contrast, we find strong evidence that foreign acquisitions can significantly improve target firms' financial conditions (decreases in the leverage ratio and increases in the liquidity ratio). The coefficient estimates of the foreign acquisition dummy are significantly different from zero at the $1 \%$ or $5 \%$ level in all 9 cases. Similar results are also found for the regression using export shares as the dependent variable. In these preliminary results, all observations are treated equally and

\footnotetext{
${ }^{16}$ Results are similar for regressions without the location dummy.
} 
did not fully take into account the pre-acquisition differences between foreign-acquired firms and their domestic counterparts. We will show next that our results hold up well after we take such differences more seriously.

In our benchmark difference-in-differences method, each foreign-acquired firm is paired with a domestic-acquired firm that has similar pre-acquisition conditions. We first focus on the effect of foreign acquisitions on target firms' productivity and highlight the importance of using domesticacquired firms as the control group to control for the productivity gains that also exist in domestic acquisitions. Then we will extend our study to broader indicators of firm performance.

\subsection{Firm Productivity}

Table 6 presents our benchmark results for firm productivity. In Panel A, firm TFP is employed as a measure of productivity, and two control groups are considered here. In both cases, foreignacquired firms are matched with domestic ones, which are used as our control group. But the first control group is picked from Chinese firms acquired by other domestic firms. In the second case, the control group is chosen from the domestic firms that experienced no change in their ownership. ${ }^{17}$ In the first case, the change in productivity is mainly due to foreign ownership after controlling for the acquisition effect that also exists in domestic acquisitions (synergy effect), while the TFP difference in the second case includes both the synergy effect and the foreign ownership effect.

First we focus on the results when the control group is chosen from domestic-acquired firms in Panel A of Table 6. In this case, TFP of foreign-acquired firms on average increased $6.2 \%$ relative to domestic-acquired firms in the year of acquisition. The increase is statistically different from zero at the $5 \%$ level. However, the productivity difference becomes insignificant in the following two years, though the coefficient estimates remain positive. This is in sharp contrast to previous

\footnotetext{
${ }^{17}$ Alternatively we can employ the multi-value treatment effect model similar to Lechner (2002) to include foreignacquired firms, domestic-acquired firms and non-acquisition domestic firms in one model. However, it is not clear how to apply the propensity score estimation method used in our paper (following Arabie and Imbence 2009) to the multi-value treatment effect model. Fukao et al. (2008) employ standard propensity score matching and differencein-differences techniques in a multinomial logit model and find that foreign acquisitions improve target firms' productivity and profits relative to acquisitions by domestic firms in Japan. However, under their nearest neighbor matching method, different non-acquisition firms are used as the control group for domestic- and foreign-acquired firms. Therefore, the differences between foreign-acquired and domestic-acquired firms are partly due to the fact that the matching control sets are different for the two categories.
} 
empirical findings that productivity gains of foreign-acquired firms are statistically significant in the acquisition year and continue to be significant in subsequent years. For instance, Arnold and Javorcik (2009) find that the productivity advantage of acquired plants in Indonesia continued to increase and reached almost $13.5 \%$ by the third year following the acquisition. Similar results are also documented by Yasar and Morrison Paul (2007) for Turkish manufacturing plants.

As we mentioned before, an important difference between our paper and previous studies is the choice of control group. We use the domestic-acquired firms as our control group to identify the purified effect of foreign ownership, while previous studies choose the control group from all domestic firms. To make our point more salient, we re-estimate our model using a control group that is chosen from all domestic firms that experienced no change in their ownership. In this case, we find larger productivity improvements for foreign-acquired firms relative to the control group: in Table 6 , the coefficient estimate is $8.1 \%$ in the acquisition year and increased to $9.6 \%$ two years after the acquisition. Note that the coefficient estimate is only $3.1 \%$ two years after the acquisition when domestic-acquired firms are used as the control group. In addition, the coefficient estimates are significantly different from zero for all three years when we use the firms with no change in their ownership as the control group, echoing previous findings in the literature. These findings suggest that both foreign- and domestic-acquired firms have experienced significant synergy gains in TFP and such gains would be inappropriately attributed to foreign ownership if they are not carefully controlled in estimation.

As robustness checks, we consider two alternative measures of productivity: gross output per employee and value-added output per employee. The evidence of productivity improvement is even weaker: none of the coefficient estimates is significantly different from zero in the acquisition year and in the subsequent two years after the acquisition. Some point estimates for the coefficient of productivity even turn negative.

\subsection{Financial Conditions and Exports}

This section presents evidence that foreign acquisitions can improve target firms' financial conditions. Recent literature emphasizes the financial channels through which FDI affects host countries' 
economies. For instance, Alfaro et al. (2004) document that economies with better-developed financial markets are able to benefit more from FDI to promote their economic growth. Their conjecture is that well-functioning local financial markets provide financing for technology spillovers from FDI firms to local firms. Manova, Wei and Zhang (forthcoming) provide firm-level empirical evidence that FDI to China can ease credit constraints for exporters and therefore promote international trade.

We provide direct evidence for the causal effect of foreign ownership on firms' financial conditions and export performance. We show that this mechanism exists in the data even after controlling for the synergy effect in domestic acquisitions. Firm productivity in the above exercises is replaced with two measures of financial conditions (the leverage and liquidity ratios) and we re-estimate the model. A robust finding is that the financial conditions of foreign-acquired firms (measured by the leverage and liquidity ratios) improve significantly relative to domestic-acquired firms. Table 7 reports our benchmark results using the difference-in-differences method combined with propensity score matching. The average leverage ratio of foreign-acquired firms declined significantly relative to domestic-acquired firms in the acquisition year and the following two years. The coefficient estimates in all three years are significantly different from zero at the $5 \%$ level. In the acquisition year, the leverage ratio of foreign-acquired firms declined 2.1 percentage points relative to domesticacquired firms. The difference remains at around 2 percentage points in the next two years.

In contrast, the liquidity ratio of foreign-acquired firms increased relative to domestic-acquired firms in the acquisition year and the subsequent two years. The coefficient estimates are significantly different from zero at the $1 \%$ level for all three years. The liquidity ratio of foreign-acquired firms increased 2.7 percentage points relative to domestic-acquired firms in the acquisition year. The difference continued to increase in the following two years and reached 4.1 percentage points in the second year following the acquisition. These findings suggest that foreign ownership significantly reduces target firms' reliance on external financing and increases the share of internal capital. The robust findings on the leverage and liquidity ratios are in sharp contrast to the evidence that foreign ownership does not significantly increase target firms' TFP after controlling for the synergy effect in domestic acquisitions. 
It is well documented in the literature that financial conditions significantly influence firms' performance. Campello (2006) points out that lower financial leverage is associated with the gains of a firm's sales relative to its competitors, while higher financial leverage leads to product market under-performance. Fresard (2010) finds that high liquidity helps firms to compete with rivals, especially rivals with tighter financing constraints, and therefore leads to an increase in the market share. These studies are consistent with our later finding that total output of foreign-acquired firms increased following the acquisition relative to domestic-acquired firms. Gamba and Triantis (2008) document that financial flexibility has a large impact on firms' overall market value. Therefore, the lower leverage ratio and higher liquidity ratio of foreign-acquired firms relative to domestic-acquired firms may strengthen the performance of foreign-acquired firms.

Manova, Wei and Zhang (forthcoming) argue that improved financial conditions help FDI firms participate in international trade. We also document that foreign acquisition can significantly improve target firms' export performance. We compare the post-acquisition changes in export shares (exports divided by total sales) of foreign-acquired and domestic-acquired firms and report our results in the last panel of Table 7. In the year of acquisition, the export share of foreignacquired firms on average increased 3.2 percentage points relative to domestic-acquired firms. It is 2.9 percentage points and 2.7 percentage points in the first and second years, respectively, following the acquisition. All coefficient estimates in these three years are significantly different from zero at the $5 \%$ level. Note that the average pre-acquisition export share of foreign-acquired firms is $28 \%$. Our results indicate a $10 \%$ increase in the export share for foreign-acquired firms relative domesticacquired firms following the acquisition. Girma et al. (2012) apply a propensity score reweighting estimator to Chinese manufacturing firms and also find that foreign acquisitions have a strong effect on exports and R\&D activities, which could be a result of improved financial conditions following the acquisition.

\subsection{Domestic-acquired Firms and Sources of Origin}

We also compare the performance of domestic-acquired firms to that of non-acquisition domestic firms and in Table 8. This exercise helps us understand the differences between domestic and for- 
eign acquisitions. Like FDI, domestic acquisitions significantly improved target firms' productivity relative to non-acquisition domestic firms. TFP of domestic-acquired firms increased about 10 percentage points relative to that of non-acquisition firms in the acquisition year and the following two years. The coefficient estimates are statistically significant at the $1 \%$ level in all three cases. This finding is consistent with previous studies on productivity gains from acquisitions. For instance, Maksimovic and Phillips (2001) document that most M\&A transactions result in productivity gains using US plant-level data. In contrast, we find no significant evidence that domestic acquisitions improve target firms' financial conditions and export shares. None of the coefficient estimates is statistically significant in all nine cases for the leverage ratio, the liquidity ratio and export shares. These findings suggest that domestic acquisitions are less motivated by financial constraints or exports than foreign acquisitions.

Previous empirical studies document that the sources of origin influence the effect of FDI on target firms (e.g., Chen, 2011). In particular, several studies document that FDI from places with ethnic Chinese ties such as Hong Kong, Macau and Taiwan (HMT) performs differently from FDI originating in other countries. For instance, Huang et al. (2013) document that FDI firms from HMT underperform non-ethnic Chinese FDI firms and the performance of ethnic Chinese firms deteriorates over time. Kamal (2014) finds that FDI from OECD countries performs better than FDI from HMT based on their productivity, profits, average wages and capital intensity.

In Table 9, we compare the performance of FDI from HMT and that from other countries and show that our main findings are robust to these two types of FDI. ${ }^{18}$ A large fraction of foreign acquisitions in China is from HMT. In our data, HMT acquisitions account for $55 \%$ of the total assets of all acquisitions in 2001. The share declined during our sample period, but remains at about $30 \%$ in more recent years. ${ }^{19}$ No significant difference is detected between HMT FDI and FDI from other countries based on their effects on firm productivity. In both cases, foreign-acquired firms do not show significant productivity improvement relative to domestic-acquired firms following the acquisition. To save space, we do not report this result in the table. However, these two types

\footnotetext{
${ }^{18}$ In this exercise, we first match foreign-acquired firms with domestic-acquired firms. Next we separate foreignacquired firms and their corresponding matched domestic-acquired firms into two sub-samples: HMT firms and FDI firms from all other countries. Then the difference-in-differences estimation is applied to each of these two sub-samples.

${ }^{19}$ Kamal (2014) documents that the share of HMT FDI in total FDI declines from $60.8 \%$ in 2001 to $45.0 \%$ in 2006.
} 
of FDI show strong effects on financial conditions and exports, and the results are reported in Table 9. We find strong evidence that FDI from HMT can significantly improve target firms' financial conditions as measured by the leverage ratio and the liquidity ratio. The leverage ratio of HMT-acquired firms declined relative to domestic-acquired firms following the acquisition, and the decrease is statistically significant at the $1 \%$ level in all three years. The evidence from the liquidity ratio is similar: the liquidity ratio of HMT-acquired firms increased relative to the domestic-acquired firms following the acquisition, and the increase is statistically significant at the $1 \%$ level in two out of three years and at the $5 \%$ level for the remaining year. We also find evidence that HMTacquired firms perform better than domestic-acquired firms in exports: the performance difference is statistically significant in two out of three years at the $1 \%$ level.

For the firms acquired by FDI from other countries, the evidence is slightly weaker for an improvement in the target firms' leverage and liquidity ratios. For both variables, the coefficient estimate is statistically significant in two out of three years at the $10 \%$ level. However, we still find strong evidence that FDI from other countries can significantly improve target firms' performance of exports: the exports of foreign-acquired firms increased relative to domestic-acquired firms following the acquisition, which is statistically significant at the $1 \%$ level in all three years that we consider. The increase in the export share is also greater than that for HMT firms.

Our results for HMT-acquired firms are consistent with Manova, Wei and Zhang's (forthcoming) findings that FDI can increase exports of target firms by relaxing their financial constraints. The firms acquired by other countries experienced a larger increase in export shares, though the evidence for financial condition improvement is weaker, compared to HMT firms. It suggests that other channels may also help FDI to promote target firms' exports. For example, FDI firms can benefit from their parent companies' market knowledge and experience when exporting to the parent companies' home countries.

\subsection{Other Performances}

Table 10 displays the results based on additional measures of firm performance: gross output, value-added output, employment, the real wage, the real profit and the real capital per worker. We 
find some evidence that foreign ownership can improve output, employment and income in our data even after controlling for the synergy effect in domestic acquisitions. Foreign ownership significantly increases total output in the acquisition year and the following two years at the $5 \%$ level. The valueadded output of foreign-acquired firms increases about 10 percentage points relative to domesticacquired firms following the acquisition. Employment of foreign-acquired firms also increases by a similar amount as output, indicating no significant improvement in productivity measured by output per worker as we have shown.

The real wage in the foreign-acquired firms also increased significantly relative to that in the domestic-acquired firms in the acquisition year and the two years following the acquisition. Using establishment-level data for the UK, Girma and Görg (2007) find sizable positive post-acquisition wage effects following acquisitions by US firms, though no such effect is detected for firms acquired by EU firms.

We find that capital inflows from foreign ownership increase the output, employment and income of the host country. Along with our findings for productivity, financial conditions and exports, these results suggest an important channel for FDI to promote the economic growth and income of host countries: foreign ownership improves target firms' financial conditions and promotes exports, which induces increases in total output, employment and income of host countries. Such gains in output, employment and labor incomes for target firms remain significant even after we control for the general gains from acquisition.

On the other hand, we barely find any evidence that foreign ownership can increase the real profit and real capital per worker relative to domestic-acquired firms. Although the real profit of foreign-acquired firms increased significantly relative to domestic-acquired firms in the acquisition year, the increase becomes insignificant in the following years. The results are robust when we use other measures of profitability such as the profit ratio (total profits divided by total sales). This may be due to the fact that many FDI firms in China are in highly competitive industries in which FDI cannot increase target firms' profitability. The real capital per worker of foreignacquired firms even declined relative to domestic-acquired firms following the acquisition. This finding is consistent with the facts that FDI improves exports and China exports labor-intensive 
products. Ma, Tang and Zhang (2014) document that Chinese firms become more labor intensive after exporting. They argue that labor-abundant countries such as China allocate more resources to labor-intensive sectors to explore their comparative advantages in international trade.

Again, to compare the differences between domestic and foreign acquisitions, we present in Table 11 the results of other performances for domestic-acquired firms. The acquisitions increased target firms' output, employment, real profit and real capital per worker relative to non-acquisition domestic firms, but reduced the real wage. The decrease of the real wage for domestic-acquired firms in Table 11 is smaller in absolute value than the increase of the real wage for foreign-acquired firms relative to domestic-acquired firms in Table 10, indicating a net positive gain in the real wage for foreign-acquired firms.

\subsection{Robustness Checks}

\section{All Registration Type Changes as Indicator of Acquisitions}

As we previously mentioned, our benchmark method of identifying acquisitions may not include all acquisitions in our sample. As a robustness check, we use all registration type changes as an indicator of acquisitions. Note that this method overestimates the number of acquisitions because registration changes may also be due to changes in other aspects such as legal status, instead of ownership.

Table A.6 reports the results for considering all registration type changes as acquisitions. As in our benchmark model, there is no significant evidence that foreign acquisitions can increase the productivity of target firms relative to domestic acquisitions, while they significantly improved target firms' financial conditions and export performance. The results are also quantitatively similar to our benchmark results: following the acquisition, the leverage ratio declined about 2 percentage points, the liquidity ratio rose 4 percentage points and the export share increased 3 percentage points.

\section{$\underline{\text { Private Firms Only }}$}

Our benchmark model includes all firms that were acquired by foreigners. However, state and collectively owned firms in China may be subject to some implicit restrictions on foreign acquisitions 
and hence behave differently in foreign acquisition activities relative to other firms. For instance, the government may prefer domestic private firms rather than foreign firms to acquire state-owned enterprises to avoid the critiques from nationalists. In this case, the conditional independence assumption may not hold: after controlling for all observable characteristics in propensity score estimation, unobserved heterogeneity may still affect firms' chance of being acquired by foreigners. In the benchmark result, we add a dummy of state/collective ownership before acquisitions to alleviate this concern. In this section, we conduct another robustness check by restricting our sample to the firms that were domestic private firms in the pre-acquisition year. The above issue is less a concern when we exclude state and collectively owned firms from our sample.

Table A.7 in the appendix reports the results when we only include private firms in our estimation. As in the benchmark model, there is no strong evidence that foreign acquisitions can significantly improve firm TFP relative to domestic acquisitions. We find similar results when using other measures of firm productivity such as output per employee. The results for the leverage and liquidity ratios are statistically significant at the $1 \%$ level in five out of six cases and at the $5 \%$ level in the remaining case. As in our benchmark model, foreign acquisitions are found to significantly promote exports in all three years at the $1 \%$ level. Indeed, our results indicate a stronger effect of FDI on exports for private firms: the coefficient estimates for private firms are more than $50 \%$ higher than those in our benchmark model. This finding is consistent with the fact that private firms contribute more than state-owned enterprises to China's export increases after 2000.

\section{$\underline{\text { Industries with Different Labor Intensities }}$}

Our results are also robust across industries with different labor intensities. Huang et al. (2008) argue that finance is an important factor explaining FDI inflows in China's labor-intensive industries such as garments. Labor-intensive industries are usually characterized by low technology and high competition. Therefore, the advantages of FDI firms are likely to come from easy access to credit rather than advanced technology for these industries. We divide 30 industries (at 2-digit industry code level) in our sample into three groups with 10 industries in each group: high, medium and low labor-intensive industries.

Table A.8 in the appendix presents the results for these three industrial groups. For all industrial 
groups, there is no significant evidence that foreign-acquired firms became more productive relative to domestic-acquired ones following the acquisition. Instead, for low labor-intensive industries, we find some evidence that foreign-acquired firms even became less productive relative to domesticacquired firms. However, such results disappear when we use other measures of firm productivity such as output per employee. As for financial constraints, the results for the liquidity ratio are quite robust across all industrial groups, though the results are less robust for the leverage ratio. The liquidity ratio significantly improved in 7 out of 9 cases at the $10 \%$ level. The results for exports also hold well across industries with different labor intensities: in 7 out of 9 cases, we find foreign-acquired firms outperform their domestic-acquired counterparts in export shares following the acquisition at the $10 \%$ level. All in all, there is no evidence that our main results are driven by labor-intensive industries.

\section{Wholly Foreign-owned FDI Firms}

Javorcik and Spatareanu (2008) document that the ownership structure affects the extent of technology spillovers of FDI firms. In particular, they find that multinationals are less likely to transfer sophisticated technologies to their partially owned subsidies than to wholly owned ones. In a robustness check, we only include FDI firms that are wholly owned by foreigners and find that our main findings hold qualitatively well in this case (Table A.9 in the appendix). FDI does not significantly improve the productivity of target firms for wholly foreign-owned firms relative to their domestic counterparts. The absolute values of the coefficient estimates for the leverage ratio and liquidity ratio are larger for wholly foreign-owned firms than those in our benchmark model, indicating a stronger effect of FDI on financial constraints for wholly foreign-owned firms. FDI is also found to significantly improve exports for wholly foreign-owned firms in two out of three years.

\section{Exporters vs. Non-exporters}

Our results are also robust when we separately estimate production functions for exporters and non-exporters. We separate exporters and non-exporters for two reasons. First, capital intensity may be different for exporters and non-exporters and it is problematic to estimate their productivity using the same production function. Ma, Tang and Zhang (2014) document that Chinese firms 
become less capital intensive after exporting and we find in this paper that FDI promotes exports of target firms. Therefore, it could be problematic to use the same production function to estimate firm TFP prior to and after acquisition. For instance, if a firm becomes an exporter following the acquisition, the capital share in the production function will decrease. If we do not take this change into account, the estimated TFP could be seriously biased. Following Ma, Tang and Zhang (2014), we separate our observations according to firms' exporting status and estimate productivity separately for exporters and non-exporters.

Second, we separate exporters and non-exporters to check whether exports increased for both groups following the acquisition. FDI can improve exports through two different channels. First, it could relax the financial constraints of non-exporters and enable them to participate in the international trade following the acquisition (extensive margin) as argued in Manova et al. (forthcoming). Alternatively, it could improve existing exporters' performance (intensive margin), for example, by better utilizing their export networks as discussed in Blonigen et al. (forthcoming). Separating exporters and non-exporters allows us to examine these two different channels.

Observations in each year are divided into two groups: one is for firms with positive exports and the other for firms with no exports. Then we estimate TFP for each group separately. Next, we divide firms into exporters and non-exporters based on their pre-acquisition status. Following Ma, Tang and Zhang (2014), if a firm exported in one or more years before acquisition, it is classified as an exporter. Otherwise, the firm is classified as a non-exporter. The difference-in-differences method is applied to exporters and non-exporters respectively to check if foreign acquisition has different impacts on firms with different pre-acquisition export statuses.

Table A.10 in the appendix reports results for exporters and non-exporters. For both types of firms, there is no significant evidence that foreign acquisitions can improve target firms' TFP relative to domestic acquisitions. Financial conditions for both exporters and non-exporters improve following the acquisition and the improvement is statistically significant in most cases. For export shares, we find a significant increase for non-exporters: the export share of firms that did not export before the acquisition increased between 4 to 6 percentage points following the acquisition. The increase in export share is statistically significant in all three years at the $1 \%$ level. This result 
is consistent with previous studies that the surviving firms that switched from non-exporters to exporters contribute significantly to China's export growth. Manova and Zhang (2009) document that surviving firms that start to export account for $70 \%$ of China's export growth between 20032005, while new firms explain the remaining $30 \%$.

The coefficient estimates of the export share are statistically insignificant for exporters in all three years considered in our exercise. However, this finding does not conclude that foreign acquisitions do not improve target firms' export performance relative to domestic acquisitions. We have shown early that foreign acquisitions improve target firms' output. As a results, there may be no significant difference in the changes of the export share between foreign- and domestic-acquired firms, even though the exports of foreign-acquired firms increased relative to domestic-acquired firms following the acquisition. In the last panel of Table A.10, we report the results for exports and find that for both exporters and non-exporters, the exports of foreign acquired firms significantly increased relative to domestic acquired firms. The difference is statistically significant for all 6 cases at the $10 \%$ level. ${ }^{20}$ This finding suggests that FDI also contributes to the increase in China's exports through the intensive margin.

\section{Processing-trade Foreign Acquisitions}

In what follows, we show that our main results are not driven by the processing trade in China. Processing trade is an important type of international trade in developing countries such as China, Indonesia and Mexico. In processing trade, domestic firms import all or part of their raw materials and intermediate inputs to process or assemble for final goods, which are re-exported to foreign countries. Firms with low-productivity and unskilled labor are usually involved in processing trade (e.g., Yu, forthcoming), which may bias our finding that foreign acquisitions do not improve target firms' productivity relative to domestic acquisitions if foreign-acquired firms engage in processing trade following the acquisition.

The Chinese transaction-level customs data indicate whether exported products are for process-

\footnotetext{
${ }^{20}$ Exports are measured by $\log (1+$ real exports $)$, where real exports equal nominal exports divided by industriallevel PPI (2-digit level). We add one to real exports before taking logs because many firms have zero exports in one or more years. Due to this reason, the coefficient estimates cannot be interpreted as percentage increases in exports.
} 
ing trade or not, and we use such information to identify processing-trade firms. ${ }^{21}$ In each year, firms are designated as processing-trade firms if they claim any of their exports as processing trade. Among 2,240 foreign acquisitions between 2001 and 2005 in our dataset, 332 target firms participated in processing trade in the pre-acquisition year. To control for firms' pre-acquisition processingtrade status, a dummy variable is added to the logit model that is employed to match foreign- and domestic-acquired firms. After the propensity-score matching, we divide foreign-acquired firms (and their matched domestic-acquired firms) into two groups according to their post-acquisition processing-trade status. The group of processing-trade foreign acquisitions include all foreignacquired firms that are involved in processing trade after the acquisition. The remaining foreignacquired firms, referred to as other foreign acquisitions, either conduct ordinary international trade or do not export at all after the acquisition. Then we perform the same difference-in-differences estimation for these two groups of firms.

Table A.11 presents our results. As in the benchmark model, we do not find evidence of productivity improvement for either processing-trade foreign acquisitions or other foreign acquisitions. There exists strong evidence that foreign acquisitions improved target firms' financial conditions based on the liquidity ratio. The liquidity ratio increased significantly at the $1 \%$ level for the foreign-acquired firms regardless of their processing-trade status. The results for the leverage ratio remain strong for the group of other foreign acquisitions, while they are weak for foreign acquisitions involving processing trade. For both groups of foreign-acquired firms, the export share significantly increased relative to domestic acquired firms following the acquisition. The export share increases are statistically significant at the $1 \%$ level in all three years for the foreign-acquired firms that pursue processing trade. For other foreign-acquired firms, the increases in the export share are quantitatively smaller but remain statistically significant at the $10 \%$ or higher levels.

Among foreign-acquired firms, the share of exporters that participate in processing trade fell from $27.7 \%$ in the acquisition year to $24.3 \%$ two years after the acquisition. This result and our finding that foreign acquisitions improve target firms' financial conditions are consistent with Manova and Yu (2011)'s finding that financial constraints affect Chinese exporters' choice of trade

\footnotetext{
${ }^{21}$ We thank Zhi Yu for providing identifications of processing-trade firms, which are obtained by combining trade data from the Chinese Customs Office and our firm-level data from the Annual Surveys of Industrial Production.
} 
regime. They document that Chinese firms with more liquid assets and less leverage pursue more ordinary trade rather than processing trade. Furthermore, financial constraints also influence trade strategies of processing-trade firms. There are two sub-categories in China's processing trade: import-and-assembly and pure assembly. The materials of pure assembly are directly provided by foreign clients, while import-and-assembly firms have to pay up-front costs to import intermediate inputs and hence require more working capital. Manova and Yu (2011) find that financially healthier enterprises are more likely to pursue import-and-assembly, which are also more profitable than pure assembly. ${ }^{22}$ Consistent with their results, we find that fewer foreign-acquired firms are involved in pure assembly as their financial conditions improved after the acquisition. Two years after the acquisition, $10 \%$ of the foreign-acquired firms participated solely in pure assembly comparing to $13.3 \%$ in the acquisition year.

\section{Conclusion}

It is well believed, especially among policymakers in developing countries, that FDI can improve the host country's productivity by the direct introduction of new technology/management and the spillover from FDI firms to local firms. Part of the belief is based on empirical evaluations on the post-acquisition performance of local firms that were acquired by foreigners. However, such evaluations may disguise the true channel through which FDI promotes the host country's economic growth and labor income if we do not carefully take into account the synergy effect that also exists in domestic acquisitions.

Using firm-level data for China during the period of 2000-2007, our study identifies the purified effect of foreign ownership by employing domestic-acquired firms as the control group. We find that relative to domestic-acquired firms, foreign acquisitions did not significantly increase Chinese firms' productivity in our data. Had foreign-acquired firms been acquired by their Chinese peers, they would have experienced similar gains in productivity. However, we do find that foreign ownership can significantly improve target firms' financial conditions as measured by the leverage and liquidity

\footnotetext{
${ }^{22}$ Manova and $\mathrm{Yu}(2011)$ use companies' shares of processing exports in total exports and shares of pure assembly in processing trade, rather than the share of firms. We are not able to follow their measures because we do not have access to the trade volume data from the Chinese Customs Office.
} 
ratios even after controlling for the synergy effect in domestic acquisitions. Foreign ownership is also found to promote target firms' exports, output, employment and the real wage. These findings provide support to recent emphasis on the financial channel through which FDI promotes international trade, labor income and economic growth of host countries.

Many developing countries provide tax and other incentives to attract FDI inflows. Such financial and policy incentives may not be as effective as providing a macroeconomic environment that can help the FDI firms to best utilize their comparative advantages. Our results show that an important advantage of FDI acquisitions relative to domestic acquisitions is to promote the international trade of the host country through improving target firms' financial conditions (and maybe through other channels too). In this case, a more effective way to attract FDI inflows is to remove trade barriers through free trade agreements and WTO membership. Our results also suggest that FDI inflows to emerging markets, such as China, may reflect the inefficiency of their financial markets. The financial market inefficiency in China comes from both its status of economic development and the administrative regulations that distort the financial markets. For instance, China's banking sector has long been dominated by state-owned banks that strongly discriminate against private firms for credit issuing. To some extent, FDI inflow is an indicator of the extent of such financial market inefficiency. Therefore, government officials should not be over-obsessed about increasing the volume of FDI inflows. The long-run goal for these emerging markets may rely on improving their financial markets' efficiency through reforms, rather than providing tax or policy incentives to maintain the level of FDI inflows.

We conclude our paper by clarifying some limits of our empirical findings and pointing out some potential topics for future studies. First, the lack of evidence for productivity gains from foreign ownership in our study does not conclude that foreign ownership itself cannot increase host countries' productivity. We focus on foreign mergers and acquisitions and exclude greenfield FDI due to the econometric method used in our study. Greenfield FDI may be more likely than foreign mergers and acquisitions to increase productivity of the host countries. One important reason for greenfield FDI is that local firms are not suitable for acquisitions due to their obsolete technology and/or management styles. In this case, greenfield FDI firms are very likely to improve 
the host country's productivity by introducing new technology and management skills (e.g., Nocke and Yeaple, 2008). Brandt et al. (2012) document a significant increase in firm-level TFP in China during the period of 1998-2007, and new entries account for over two-thirds of the increase in TFP. It is of interest to investigate the role of FDI in the TFP increase due to new entries.

Second, our results might also depend on the technology gap between the host and source countries of FDI. ${ }^{23}$ China's productivity growth has accelerated since the early 1980s, after it adopted radical domestic economic reforms and integrated its economy into the global economy through international trade and capital flows. As a result, the technology gap between Chinese firms and their foreign counterparts shrank dramatically during this period. It is very likely that the productivity gains from foreign ownership might have disappeared in our sample period that starts in 2000. However, this does not exclude the possibility that foreign ownership improved China's productivity in the 1990s when Chinese firms lagged further behind their peers in advanced economies. Due to data unavailability, we are unable to check this possibility.

Last but not least, we focus on the effect of foreign acquisitions on target firms and did not consider their spillovers to domestic firms. As we have mentioned, both positive and negative spillovers are detected in previous empirical studies. In particular, Harrison and McMillan (2003) use firm-level data from the Ivory Coast to document that foreign firms borrow from domestic banks and such borrowing exacerbates domestic firm credit constraint. The evaluation of FDI's overall effect should also take into account these spillovers and deserves further exploration in the future.

\footnotetext{
${ }^{23}$ For instance, Chen (2011) and Kamal (2014) document that the source of origin of FDI influences the performance of target firms.
} 
Figure 1: TFP of Foreign- and Domestic-acquired Firms Across Time

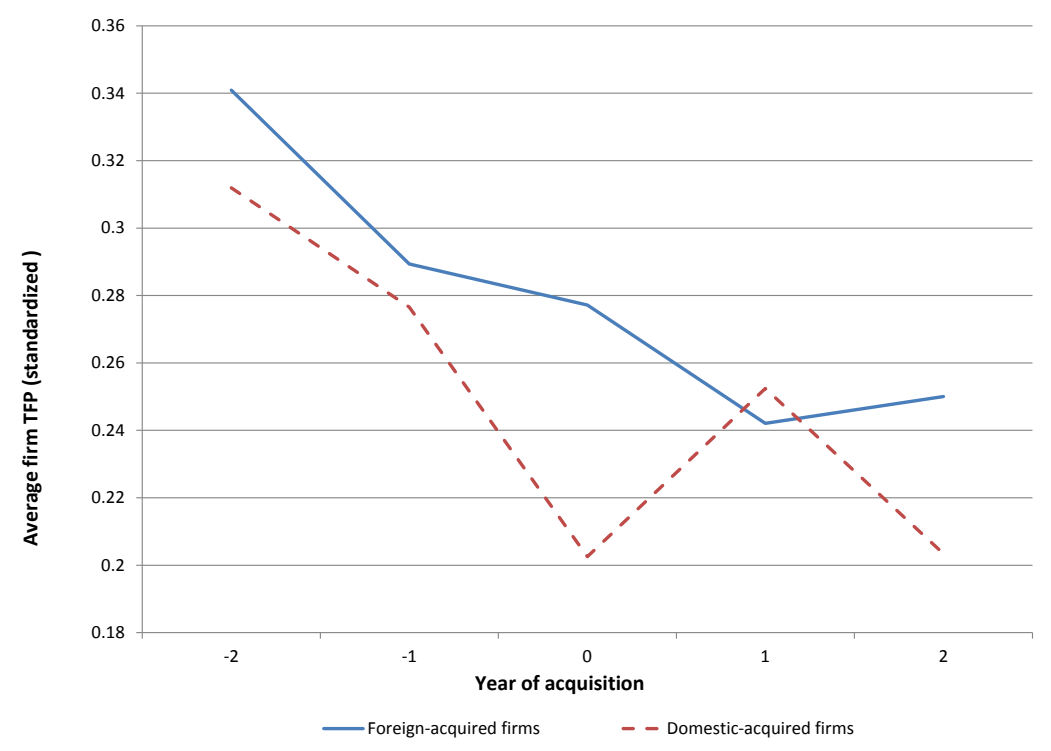

Note:

-TFP is measured by firm TFP minus the industrial average and divided by the industrial standard deviation. See Section 3.2 for details. The domestic-acquired firms are matched with the foreign-acquired firms based on their characteristics in the pre-acquisition year. 
Table 1: Summary Statistics

\begin{tabular}{|c|c|c|c|c|c|c|c|c|c|c|}
\hline & \multicolumn{2}{|c|}{2001} & \multicolumn{2}{|c|}{2002} & \multicolumn{2}{|c|}{2003} & \multicolumn{2}{|c|}{2004} & \multicolumn{2}{|c|}{2005} \\
\hline & Mean & Std Dev & Mean & Std Dev & Mean & Std Dev & Mean & Std Dev & Mean & Std Dev \\
\hline TFP & $0 \cdot 161$ & $0 \cdot 861$ & $0 \cdot 130$ & $0 \cdot 873$ & $0 \cdot 112$ & 0.924 & $0 \cdot 083$ & $0 \cdot 957$ & $0 \cdot 087$ & 0.947 \\
\hline Employment & $5 \cdot 195$ & $1 \cdot 161$ & $5 \cdot 177$ & $1 \cdot 161$ & $5 \cdot 124$ & $1 \cdot 168$ & $5 \cdot 030$ & $1 \cdot 165$ & $5 \cdot 065$ & $1 \cdot 183$ \\
\hline Real wage & 1.986 & $0 \cdot 694$ & $2 \cdot 073$ & $0 \cdot 709$ & $2 \cdot 134$ & $0 \cdot 708$ & $2 \cdot 319$ & 0.552 & $2 \cdot 417$ & 0.589 \\
\hline Real capital/worker & $3 \cdot 587$ & $1 \cdot 213$ & $3 \cdot 665$ & $1 \cdot 229$ & $3 \cdot 718$ & $1 \cdot 265$ & $3 \cdot 745$ & $1 \cdot 297$ & $3 \cdot 815$ & $1 \cdot 282$ \\
\hline Age & $14 \cdot 231$ & $14 \cdot 041$ & $14 \cdot 132$ & $13 \cdot 904$ & $13 \cdot 174$ & $13 \cdot 434$ & $11 \cdot 680$ & $12 \cdot 471$ & $12 \cdot 051$ & $12 \cdot 498$ \\
\hline Export share & $0 \cdot 101$ & $0 \cdot 255$ & $0 \cdot 104$ & $0 \cdot 260$ & $0 \cdot 107$ & $0 \cdot 265$ & $0 \cdot 111$ & $0 \cdot 271$ & $0 \cdot 106$ & $0 \cdot 26$ \\
\hline Leverage ratio & $0 \cdot 590$ & $0 \cdot 232$ & $0 \cdot 580$ & $0 \cdot 234$ & $0 \cdot 570$ & $0 \cdot 236$ & $0 \cdot 576$ & $0 \cdot 237$ & $0 \cdot 560$ & $0 \cdot 240$ \\
\hline Liquidity ratio & $0 \cdot 027$ & $0 \cdot 347$ & $0 \cdot 037$ & $0 \cdot 324$ & $0 \cdot 044$ & $0 \cdot 316$ & $0 \cdot 041$ & $0 \cdot 345$ & $0 \cdot 051$ & $0 \cdot 328$ \\
\hline
\end{tabular}

- This table displays the summary statistics of variables for domestic- and foreign-acquired firms in our data.

- See Section 3 for data description and the definitions of variables in the table.

- Variables of TFP, Employment, Real wage and Real capital/worker are in logarithms and other variables are in levels.

Table 2: Number of Firms in Different Types of Acquisitions

\begin{tabular}{l|c|c|c}
\hline \hline Year & Total Number of Firms & Domestic to Domestic & Domestic to Foreign \\
\hline 2001 & 104,438 & 4,300 & 537 \\
2002 & 103,398 & 2,788 & 253 \\
2003 & 106,152 & 4,095 & 357 \\
2004 & 139,112 & 6,349 & 835 \\
2005 & 130,956 & 3,391 & 258 \\
2006 & 138,792 & 3,578 & 580 \\
2007 & 153,861 & 2,334 & 711 \\
\hline Average & 125,244 & 3,834 & 504 \\
\hline \hline
\end{tabular}

- Column "Domestic to Domestic" shows the number of firms whose registration type changed from one of the domestic categories to another type in the domestic categories. These firms are considered as domestic-acquired firms.

- Column "Domestic to Foreign" shows the number of firms whose registration type changed from one of the domestic categories to the foreign category. These firms are considered as foreign-acquired firms.

- See Section 3 for the definitions of domestic and foreign categories of firm registrations. 
Table 3: Estimation Results of the Logit Model

\begin{tabular}{|c|c|c|c|c|c|c|}
\hline & Coefficient & Std. Err & $z$ & $\mathrm{P}>|z|$ & \multicolumn{2}{|c|}{$95 \%$ Conf. Interval } \\
\hline TFP & $0 \cdot 056^{*}$ & $0 \cdot 031$ & $1 \cdot 800$ & $0 \cdot 072$ & $-0 \cdot 005$ & $0 \cdot 118$ \\
\hline Employment & $0 \cdot 111^{* * *}$ & $0 \cdot 022$ & $4 \cdot 960$ & $0 \cdot 000$ & $0 \cdot 067$ & $0 \cdot 155$ \\
\hline Real wage & $0 \cdot 286^{* * *}$ & $0 \cdot 039$ & $7 \cdot 320$ & $0 \cdot 000$ & $0 \cdot 209$ & $0 \cdot 363$ \\
\hline Age & $-0 \cdot 045^{* * *}$ & $0 \cdot 003$ & -14.510 & $0 \cdot 000$ & $-0 \cdot 051$ & $-0 \cdot 039$ \\
\hline Real capital per worker & $0 \cdot 123^{* * *}$ & $0 \cdot 023$ & $5 \cdot 330$ & $0 \cdot 000$ & $0 \cdot 078$ & $0 \cdot 168$ \\
\hline Export status & $1 \cdot 118^{* * *}$ & $0 \cdot 056$ & $20 \cdot 140$ & $0 \cdot 000$ & $1 \cdot 009$ & $1 \cdot 227$ \\
\hline Leverage ratio & $-0 \cdot 332^{* *}$ & $0 \cdot 137$ & $-2 \cdot 420$ & $0 \cdot 016$ & $-0 \cdot 601$ & $-0 \cdot 063$ \\
\hline Liquidity ratio & $0 \cdot 503^{* * *}$ & $0 \cdot 129$ & 3.900 & $0 \cdot 000$ & $0 \cdot 250$ & $0 \cdot 757$ \\
\hline Dummy of state/collectively owned & $-0 \cdot 821^{* * *}$ & $0 \cdot 055$ & -14.920 & $0 \cdot 000$ & $-0 \cdot 929$ & $-0 \cdot 714$ \\
\hline
\end{tabular}

- All variables are measured in their pre-acquisition year except for age.

- Employment, Real wage and Real capital/worker are in logarithms.

- Export status is a dummy variable that equals one if the firm is an exporter and zero otherwise.

- Dummy of state/collectively owned equals one if the firm is a state or collectively owned enterprise and zero otherwise.

- Results for the acquisition year dummy and the industry dummy (2-digit level industrial code) are not reported in the table to save space.

$-{ }^{*},{ }^{* *}$ and ${ }^{* * *}$ denote significance at the $10 \%, 5 \%$ and $1 \%$ levels respectively.

Table 4: Balance Test of Matching Covariates in Propensity Score Matching

\begin{tabular}{l|ccc|rc}
\hline \hline & \multicolumn{3}{|c|}{ Mean } & \multicolumn{2}{c}{ t-test } \\
\cline { 2 - 6 } & Treatment & Control & Bias (\%) & \multicolumn{1}{c}{$t$} & $p>|t|$ \\
\hline TFP & $0 \cdot 29$ & 0.28 & 1.50 & 0.48 & 0.63 \\
Employment & $5 \cdot 19$ & $5 \cdot 22$ & $-2 \cdot 30$ & -0.75 & 0.45 \\
Real wage & $2 \cdot 28$ & $2 \cdot 24$ & 4.20 & 1.35 & 0.18 \\
Age & 7.99 & $8 \cdot 05$ & -0.70 & -0.23 & 0.82 \\
Real capital per worker & $3 \cdot 67$ & 3.69 & -1.30 & -0.43 & 0.67 \\
Export status & 0.48 & 0.47 & 2.50 & 0.81 & 0.42 \\
Leverage ratio & 0.54 & 0.54 & -0.10 & -0.05 & 0.96 \\
Liquidity ratio & 0.11 & 0.12 & -2.90 & -0.92 & 0.36 \\
Dummy of state/collective owned & 0.30 & 0.28 & 3.20 & 1.03 & 0.30 \\
\hline \hline
\end{tabular}

- See footnotes in Table 3 for details about the variables in this table.

- Columns two and three report the means of the treatment and control groups, respectively.

- Column "Bias (\%)" displays the percentage deviations of the mean of the treatment group from that of the control group ( $\frac{\text { treatment group mean - control group mean }}{\text { treatment group mean }} \times 100$ ).

- The null hypothesis of the t-test is that the treatment and control groups have the same sample means.

$-^{*},{ }^{* *}$ and ${ }^{* * *}$ denote significance at the $10 \%, 5 \%$ and $1 \%$ levels respectively. 
Table 5: Results for OLS Regressions

\begin{tabular}{c|ccc|ccc|ccc}
\hline \hline \multirow{2}{*}{$\begin{array}{c}\text { Dependent } \\
\text { variable }\end{array}$} & \multicolumn{3}{|c|}{ Acquisition year } & \multicolumn{3}{c|}{ One year after } & \multicolumn{3}{c}{ Two years after } \\
\cline { 2 - 10 } & Coeff. & Std. Err & $\mathrm{P}>|z|$ & Coeff. & Std. Err & $\mathrm{P}>|z|$ & Coeff. & Std. Err & $\mathrm{P}>|z|$ \\
\hline Productivity 1 & 0.021 & 0.017 & 0.231 & -0.009 & 0.021 & 0.673 & $0.043^{*}$ & 0.026 & 0.098 \\
Productivity 2 & $-0.028^{*}$ & 0.014 & 0.051 & $-0.035^{*}$ & 0.018 & 0.049 & -0.022 & 0.024 & 0.345 \\
Productivity 3 & -0.001 & 0.021 & 0.963 & -0.036 & 0.025 & 0.150 & 0.003 & 0.030 & 0.930 \\
Leverage ratio & $-0.019^{* * *}$ & 0.003 & 0.000 & $-0.021^{* * *}$ & 0.005 & 0.000 & $-0.015^{* *}$ & 0.006 & 0.019 \\
Liquidity ratio & $0.029^{* * *}$ & 0.005 & 0.000 & $0.036^{* * *}$ & 0.007 & 0.000 & $0.036^{* * *}$ & 0.009 & 0.000 \\
Export share & $0.027^{* * *}$ & 0.005 & 0.000 & $0.032^{* * *}$ & 0.005 & 0.000 & $0.028^{* * *}$ & 0.008 & 0.000 \\
\hline \hline
\end{tabular}

- This table reports the estimation results for the foreign acquisition dummy in the simple OLS regressions discussed in Section 4. Complete estimation results are reported in the appendix (Tables A.2-A.5).

- The first column shows the dependent variable of each regression and each row presents the estimation results for the foreign acquisition dummy.

- Productivity 1 is measured by TFP, Productivity 2 is measured by gross output per employee and Productivity 3 is measured by value-added output per employee.

$-^{*},{ }^{* *}$ and ${ }^{* * *}$ denote significance at the $10 \%, 5 \%$ and $1 \%$ levels respectively. 
Table 6: Benchmark Results for Productivity

\begin{tabular}{c|cccc|cc}
\hline \hline \multicolumn{7}{c}{ Panel A: TFP as measure of productivity } \\
\hline \multicolumn{7}{c}{ Control group: domestic-acquired firms } \\
\hline & Coefficient & Std. Err & $z$ & $\mathrm{P}>|z|$ & $95 \%$ Conf. Interval \\
\hline Acquisition year & $0 \cdot 062^{* *}$ & $0 \cdot 025$ & $2 \cdot 480$ & $0 \cdot 013$ & $0 \cdot 013$ & $0 \cdot 111$ \\
One year after & $0 \cdot 003$ & $0 \cdot 032$ & $0 \cdot 090$ & $0 \cdot 930$ & $-0 \cdot 060$ & $0 \cdot 066$ \\
Two years after & $0 \cdot 031$ & $0 \cdot 035$ & $0 \cdot 900$ & $0 \cdot 369$ & $-0 \cdot 037$ & $0 \cdot 099$ \\
\hline \hline & Control group: domestic firms with no acquisition & \\
\hline & Coefficient & Std. Err & $z$ & $\mathrm{P}>|z|$ & $95 \%$ Conf. Interval \\
\hline Acquisition year & $0 \cdot 081^{* *}$ & $0 \cdot 036$ & $2 \cdot 240$ & $0 \cdot 025$ & $0 \cdot 010$ & $0 \cdot 152$ \\
One year after & $0 \cdot 080^{* *}$ & $0 \cdot 039$ & $2 \cdot 070$ & $0 \cdot 039$ & $0 \cdot 004$ & $0 \cdot 157$ \\
Two years after & $0 \cdot 096^{* *}$ & $0 \cdot 046$ & $2 \cdot 060$ & $0 \cdot 040$ & $0 \cdot 005$ & $0 \cdot 187$ \\
\hline
\end{tabular}

Panel B: Gross output per employee as measure of productivity

Control group: domestic-acquired firms

\begin{tabular}{c|rrrr|rc}
\hline & Coefficient & Std. Err & \multicolumn{1}{c}{$z$} & $\mathrm{P}>|z|$ & $95 \%$ Conf. Interval \\
\hline Acquisition year & $0 \cdot 011$ & $0 \cdot 023$ & $0 \cdot 480$ & $0 \cdot 633$ & $-0 \cdot 034$ & $0 \cdot 056$ \\
One year after & $0 \cdot 016$ & $0 \cdot 029$ & 0.550 & 0.581 & -0.041 & $0 \cdot 073$ \\
Two years after & -0.045 & 0.034 & -1.320 & $0 \cdot 186$ & -0.112 & 0.022 \\
\hline \hline
\end{tabular}

Panel C: Value-added output per employee as measure of productivity

\begin{tabular}{c|cccr|cc}
\hline \multicolumn{7}{c}{ Control: domestic-acquired firms } \\
\hline & Coefficient & Std. Err & \multicolumn{1}{c}{$z$} & $\mathrm{P}>|z|$ & $95 \%$ Conf. Interval \\
\hline Acquisition year & $0 \cdot 023$ & $0 \cdot 028$ & $0 \cdot 850$ & $0 \cdot 398$ & $-0 \cdot 031$ & $0 \cdot 078$ \\
One year after & $0 \cdot 034$ & $0 \cdot 038$ & $0 \cdot 880$ & $0 \cdot 377$ & -0.041 & $0 \cdot 109$ \\
Two years after & -0.012 & $0 \cdot 044$ & -0.280 & $0 \cdot 782$ & -0.098 & $0 \cdot 074$ \\
\hline \hline
\end{tabular}

- This table reports the benchmark results for the effect of foreign ownership on target firms' productivity.

- Panels A, B and C use TFP, gross output per employee and value-added output per employee as the measure of firm productivity, respectively.

- Panel A considers two cases for the control group: firms that are acquired by domestic firms in the first case (the benchmark model) and firms that experienced no acquisition in the second case.

$-^{*},{ }^{* *}$ and ${ }^{* * *}$ denote significance at the $10 \%, 5 \%$ and $1 \%$ levels respectively. 
Table 7: Benchmark Results for Financial Conditions and Exports

\begin{tabular}{|c|c|c|c|c|c|c|}
\hline \multicolumn{7}{|c|}{ Leverage ratio } \\
\hline & Coefficient & Std. Err & $z$ & $\mathrm{P}>|z|$ & $95 \%$ Conf & Interval \\
\hline Acquisition year & $-0 \cdot 021^{* * *}$ & $0 \cdot 006$ & $-3 \cdot 500$ & $0 \cdot 000$ & $-0 \cdot 034$ & $-0 \cdot 009$ \\
\hline One year after & $-0 \cdot 021^{* * *}$ & $0 \cdot 007$ & $-2 \cdot 810$ & $0 \cdot 005$ & $-0 \cdot 035$ & $-0 \cdot 006$ \\
\hline Two years after & $-0 \cdot 020^{* *}$ & $0 \cdot 009$ & $-2 \cdot 210$ & $0 \cdot 027$ & $-0 \cdot 038$ & -0.002 \\
\hline \multicolumn{7}{|c|}{ Liquidity ratio } \\
\hline & Coefficient & Std. Err & $z$ & $\mathrm{P}>|z|$ & $95 \%$ Conf & Interval \\
\hline Acquisition year & $0 \cdot 027^{* * *}$ & $0 \cdot 008$ & $3 \cdot 420$ & $0 \cdot 001$ & $0 \cdot 012$ & $0 \cdot 042$ \\
\hline One year after & $0 \cdot 041^{* * *}$ & $0 \cdot 009$ & $4 \cdot 480$ & $0 \cdot 000$ & $0 \cdot 023$ & $0 \cdot 059$ \\
\hline Two years after & $0 \cdot 041^{* * *}$ & $0 \cdot 011$ & $3 \cdot 570$ & $0 \cdot 000$ & $0 \cdot 018$ & $0 \cdot 063$ \\
\hline \multicolumn{7}{|c|}{ Export share } \\
\hline & Coefficient & Std. Err & $z$ & $\mathrm{P}>|z|$ & $95 \%$ Conf & Interval \\
\hline Acquisition year & $0 \cdot 032^{* * *}$ & $0 \cdot 009$ & $3 \cdot 590$ & $0 \cdot 000$ & $0 \cdot 014$ & $0 \cdot 049$ \\
\hline One year after & $0 \cdot 029^{* * *}$ & $0 \cdot 010$ & $2 \cdot 980$ & $0 \cdot 003$ & $0 \cdot 010$ & $0 \cdot 048$ \\
\hline Two years after & $0 \cdot 027^{* *}$ & $0 \cdot 012$ & $2 \cdot 300$ & $0 \cdot 022$ & $0 \cdot 004$ & $0 \cdot 050$ \\
\hline
\end{tabular}

- This table reports the benchmark results for the effect of foreign ownership on target firms' financial conditions and exports.

- The treatment group includes foreign-acquired firms and the control group includes domestic-acquired firms that are paired with foreign-acquired firms using the propensity score matching method.

$-^{*},{ }^{* *}$ and ${ }^{* * *}$ denote significance at the $10 \%, 5 \%$ and $1 \%$ levels respectively. 
Table 8: Results for Domestic-acquired Firms

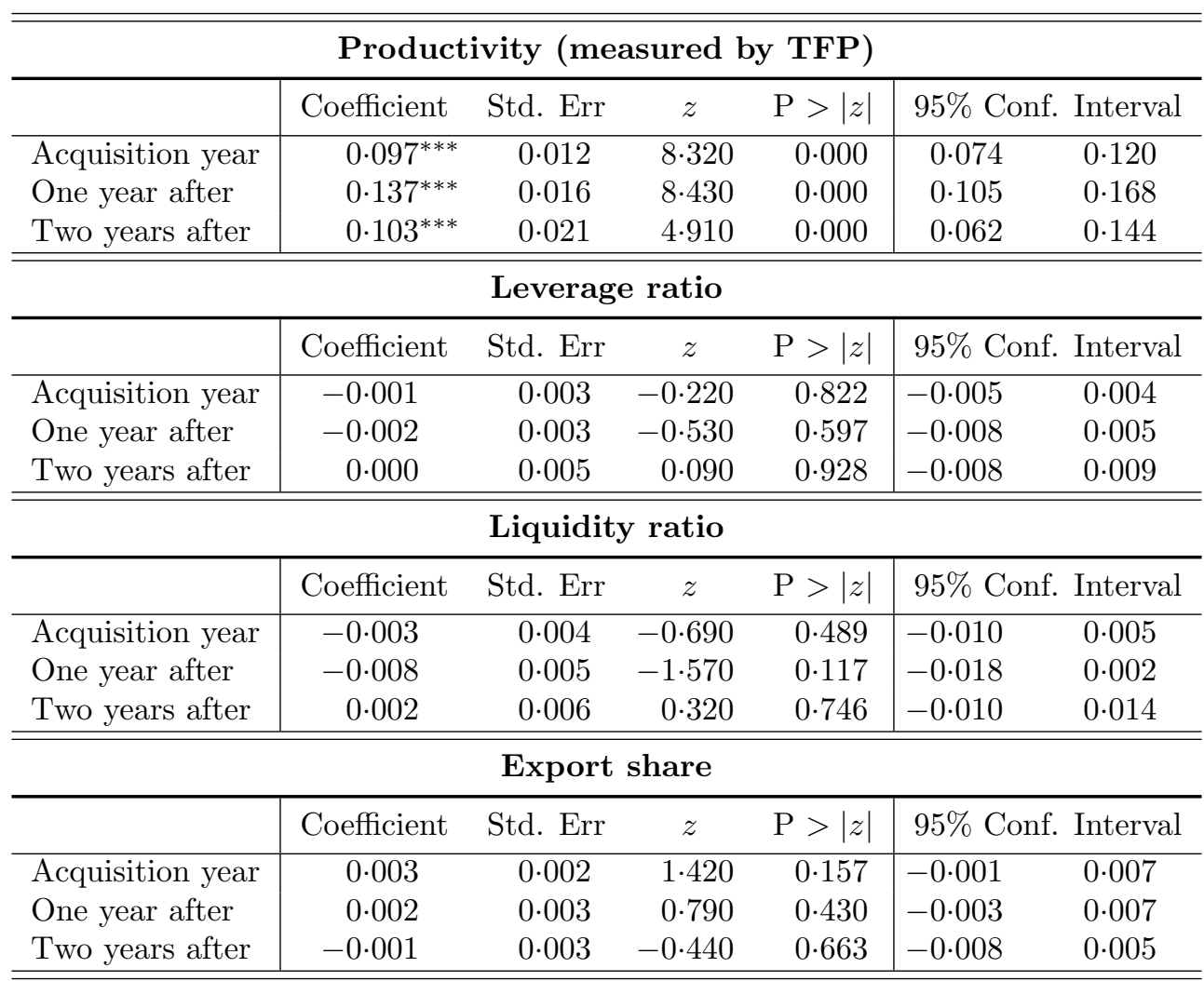

- This table reports the results for domestic-acquired firms.

- The treatment group includes domestic-acquired firms and the control group includes non-acquisition firms that are paired with domestic-acquired firms using the propensity score matching method.

$-^{*},{ }^{* *}$ and ${ }^{* * *}$ denote significance at the $10 \%, 5 \%$ and $1 \%$ levels respectively. 
Table 9: Effects of FDI from Different Sources

\begin{tabular}{|c|c|c|c|c|c|c|}
\hline \multicolumn{7}{|c|}{ Panel A: Firms from Hong Kong, Macau and Taiwan } \\
\hline \multicolumn{7}{|c|}{ Leverage ratio } \\
\hline & Coefficient & Std. Err & $z$ & $\mathrm{P}>|z|$ & $95 \%$ Conf. & Interval \\
\hline Acquisition Year & $-0 \cdot 019^{* * *}$ & $0 \cdot 006$ & $-3 \cdot 317$ & $0 \cdot 001$ & $-0 \cdot 030$ & $-0 \cdot 008$ \\
\hline One year after & $-0.038^{* * *}$ & $0 \cdot 007$ & $-5 \cdot 387$ & $0 \cdot 000$ & $-0 \cdot 051$ & $-0 \cdot 024$ \\
\hline Two years after & $-0 \cdot 018^{* * *}$ & $0 \cdot 007$ & $-2 \cdot 621$ & $0 \cdot 009$ & $-0 \cdot 032$ & $-0 \cdot 005$ \\
\hline \multicolumn{7}{|c|}{ Liquidity ratio } \\
\hline & Coefficient & Std. Err & $z$ & $\mathrm{P}>|z|$ & $95 \%$ Conf. & Interval \\
\hline Acquisition Year & $0 \cdot 023^{* *}$ & $0 \cdot 011$ & $2 \cdot 122$ & $0 \cdot 034$ & $0 \cdot 002$ & $0 \cdot 044$ \\
\hline One year after & $0 \cdot 062^{* * *}$ & $0 \cdot 011$ & $5 \cdot 790$ & $0 \cdot 000$ & $0 \cdot 041$ & $0 \cdot 083$ \\
\hline Two years after & $0 \cdot 056^{* * *}$ & $0 \cdot 012$ & $4 \cdot 681$ & $0 \cdot 000$ & $0 \cdot 033$ & $0 \cdot 079$ \\
\hline \multicolumn{7}{|c|}{ Export share } \\
\hline & Coefficient & Std. Err & $z$ & $\mathrm{P}>|z|$ & $95 \%$ Conf. & Interval \\
\hline Acquisition Year & $0 \cdot 027^{* * *}$ & $0 \cdot 008$ & $3 \cdot 326$ & $0 \cdot 001$ & $0 \cdot 011$ & $0 \cdot 044$ \\
\hline One year after & $0 \cdot 029^{* * *}$ & $0 \cdot 007$ & $3 \cdot 865$ & $0 \cdot 000$ & $0 \cdot 014$ & $0 \cdot 043$ \\
\hline Two years after & $0 \cdot 029^{* * *}$ & $0 \cdot 008$ & $3 \cdot 739$ & $0 \cdot 000$ & $0 \cdot 014$ & $0 \cdot 044$ \\
\hline \multicolumn{7}{|c|}{ Panel B: Firms from other countries } \\
\hline \multicolumn{7}{|c|}{ Leverage ratio } \\
\hline & Coefficient & Std. Err & $z$ & $\mathrm{P}>|z|$ & $95 \%$ Conf. & Interval \\
\hline Acquisition Year & $-0 \cdot 025^{* * *}$ & $0 \cdot 006$ & $-4 \cdot 178$ & $0 \cdot 000$ & $-0 \cdot 036$ & $-0 \cdot 013$ \\
\hline One year after & $-0 \cdot 002$ & $0 \cdot 006$ & $-0 \cdot 277$ & $0 \cdot 782$ & $-0 \cdot 013$ & $0 \cdot 010$ \\
\hline Two years after & $-0 \cdot 023^{* * *}$ & $0 \cdot 007$ & $-3 \cdot 055$ & $0 \cdot 002$ & $-0 \cdot 037$ & $-0 \cdot 008$ \\
\hline \multicolumn{7}{|c|}{ Liquidity ratio } \\
\hline & Coefficient & Std. Err & $z$ & $\mathrm{P}>|z|$ & 95\% Conf. & Interval \\
\hline Acquisition Year & $0 \cdot 032^{* * *}$ & $0 \cdot 010$ & $3 \cdot 287$ & $0 \cdot 001$ & $0 \cdot 013$ & $0 \cdot 051$ \\
\hline One year after & $0 \cdot 017$ & $0 \cdot 011$ & $1 \cdot 645$ & $0 \cdot 100$ & $-0 \cdot 003$ & $0 \cdot 038$ \\
\hline Two years after & $0 \cdot 023^{*}$ & $0 \cdot 013$ & 1.756 & $0 \cdot 079$ & $-0 \cdot 003$ & $0 \cdot 049$ \\
\hline \multicolumn{7}{|c|}{ Export share } \\
\hline & Coefficient & Std. Err & $z$ & $\mathrm{P}>|z|$ & 95\% Conf. & Interval \\
\hline Acquisition Year & $0 \cdot 031^{* * *}$ & 0.007 & $4 \cdot 328$ & $0 \cdot 000$ & $0 \cdot 017$ & $0 \cdot 045$ \\
\hline One year after & $0.053^{* * *}$ & 0.007 & $7 \cdot 454$ & $0 \cdot 000$ & 0.039 & $0 \cdot 067$ \\
\hline Two years after & $0 \cdot 045^{* * *}$ & 0.008 & $5 \cdot 315$ & $0 \cdot 000$ & $0 \cdot 028$ & $0 \cdot 061$ \\
\hline
\end{tabular}

- This table reports the results for the effect of foreign ownership on target firms' financial conditions and exports for FDI with different sources of origin.

- The treatment group in panels A and B includes foreign-acquired firms from different sources and the control group includes domestic-acquired firms that are paired with these foreign-acquired firms using the propensity score matching method.

$-^{*},{ }^{* *}$ and ${ }^{* * *}$ denote significance at the $10 \%, 5 \%$ and $1 \%$ levels respectively. 
Table 10: Benchmark Results for Other Performance

\begin{tabular}{|c|c|c|c|c|c|c|}
\hline \multicolumn{7}{|c|}{ Gross output } \\
\hline & Coefficient & Std. Err & $z$ & $\mathrm{P}>|z|$ & 95\% Conf & Interval \\
\hline Acquisition year & $0 \cdot 051^{* *}$ & $0 \cdot 021$ & $2 \cdot 510$ & $0 \cdot 012$ & $0 \cdot 011$ & $0 \cdot 092$ \\
\hline One year after & $0 \cdot 088^{* * *}$ & $0 \cdot 026$ & $3 \cdot 440$ & $0 \cdot 001$ & $0 \cdot 038$ & $0 \cdot 138$ \\
\hline Two years after & $0 \cdot 106^{* * *}$ & $0 \cdot 036$ & $2 \cdot 950$ & $0 \cdot 003$ & $0 \cdot 036$ & $0 \cdot 177$ \\
\hline \multicolumn{7}{|c|}{ Value-added output } \\
\hline & Coefficient & Std. Err & $z$ & $\mathrm{P}>|z|$ & $95 \%$ Conf & Interval \\
\hline Acquisition year & $0 \cdot 119^{* * *}$ & $0 \cdot 029$ & $4 \cdot 110$ & $0 \cdot 000$ & $0 \cdot 062$ & $0 \cdot 176$ \\
\hline One year after & $0 \cdot 083^{* *}$ & $0 \cdot 036$ & $2 \cdot 290$ & $0 \cdot 022$ & $0 \cdot 012$ & $0 \cdot 155$ \\
\hline Two years after & $0 \cdot 101^{* *}$ & $0 \cdot 043$ & $2 \cdot 370$ & $0 \cdot 018$ & $0 \cdot 017$ & $0 \cdot 184$ \\
\hline \multicolumn{7}{|c|}{ Employment } \\
\hline & Coefficient & Std. Err & $z$ & $\mathrm{P}>|z|$ & $95 \%$ Conf & Interval \\
\hline Acquisition year & $0 \cdot 070^{* * *}$ & $0 \cdot 019$ & $3 \cdot 640$ & $0 \cdot 000$ & $0 \cdot 032$ & $0 \cdot 108$ \\
\hline One year after & $0 \cdot 091^{* * *}$ & $0 \cdot 025$ & $3 \cdot 690$ & $0 \cdot 000$ & $0 \cdot 043$ & $0 \cdot 140$ \\
\hline Two years after & $0 \cdot 118^{* * *}$ & $0 \cdot 032$ & $3 \cdot 760$ & $0 \cdot 000$ & $0 \cdot 057$ & $0 \cdot 180$ \\
\hline \multicolumn{7}{|c|}{ Real wage } \\
\hline & Coefficient & Std. Err & $z$ & $\mathrm{P}>|z|$ & $95 \%$ Conf & Interval \\
\hline Acquisition year & $0 \cdot 051^{* *}$ & $0 \cdot 021$ & $2 \cdot 490$ & $0 \cdot 013$ & $0 \cdot 011$ & $0 \cdot 092$ \\
\hline One year after & $0 \cdot 059^{* *}$ & $0 \cdot 026$ & $2 \cdot 300$ & $0 \cdot 021$ & $0 \cdot 009$ & $0 \cdot 109$ \\
\hline Two years after & $0 \cdot 075^{* * *}$ & $0 \cdot 025$ & $3 \cdot 000$ & $0 \cdot 003$ & $0 \cdot 026$ & $0 \cdot 124$ \\
\hline \multicolumn{7}{|c|}{ Real profit } \\
\hline & Coefficient & Std. Err & $z$ & $\mathrm{P}>|z|$ & $95 \%$ Conf & Interval \\
\hline Acquisition year & $0 \cdot 125^{* *}$ & $0 \cdot 051$ & $2 \cdot 480$ & $0 \cdot 013$ & $0 \cdot 026$ & $0 \cdot 224$ \\
\hline One year after & $0 \cdot 047$ & $0 \cdot 065$ & $0 \cdot 730$ & $0 \cdot 466$ & $-0 \cdot 080$ & $0 \cdot 174$ \\
\hline Two years after & $-0 \cdot 069$ & $0 \cdot 081$ & $-0 \cdot 850$ & $0 \cdot 395$ & $-0 \cdot 229$ & $0 \cdot 090$ \\
\hline
\end{tabular}

Real capital per worker

\begin{tabular}{l|cccc|cc}
\hline & Coefficient & Std. Err & $z$ & $\mathrm{P}>|z|$ & \multicolumn{2}{c}{$95 \%$ Conf. Interval } \\
\hline Acquisition year & $-0.080^{* * *}$ & 0.026 & -3.010 & 0.003 & -0.132 & -0.028 \\
One year after & -0.050 & 0.034 & -1.490 & 0.138 & -0.117 & 0.016 \\
Two years after & -0.029 & 0.045 & -0.640 & 0.520 & -0.118 & 0.060 \\
\hline \hline
\end{tabular}

- This table reports the benchmark results for the effect of foreign ownership on target firms' other performance. All measures of firm performance are in logarithms.

- The treatment group includes foreign-acquired firms and the control group includes domestic-acquired firms that are paired with foreign-acquired firms using the propensity score matching method.

${ }^{*},{ }^{* *}$ and ${ }^{* * *}$ denote significance at the $10 \%, 5 \%$ and $1 \%$ levels respectively. 
Table 11: Other Performance of Domestic-acquired Firms

\begin{tabular}{|c|c|c|c|c|c|}
\hline \multicolumn{6}{|c|}{ Gross output } \\
\hline & Coefficient & Std. Err & $z$ & $\mathrm{P}>|z|$ & 95\% Conf. Interval \\
\hline Acquisition year & $0 \cdot 091^{* * *}$ & $0 \cdot 009$ & $10 \cdot 020$ & $0 \cdot 000$ & $0 \cdot 109$ \\
\hline One year after & $0 \cdot 135^{* * *}$ & $0 \cdot 014$ & $9 \cdot 610$ & $0 \cdot 000$ & $0 \cdot 163$ \\
\hline Two years after & $0 \cdot 143^{* * *}$ & $0 \cdot 018$ & $7 \cdot 930$ & $0 \cdot 000$ & $0 \cdot 178$ \\
\hline \multicolumn{6}{|c|}{ Employment } \\
\hline & Coefficient & Std. Err & $z$ & $\mathrm{P}>|z|$ & $95 \%$ Conf. Interval \\
\hline Acquisition year & $0 \cdot 045^{* * *}$ & $0 \cdot 007$ & $6 \cdot 170$ & $0 \cdot 000$ & $0 \cdot 030$ \\
\hline One year after & $0 \cdot 078^{* * *}$ & $0 \cdot 010$ & $7 \cdot 570$ & $0 \cdot 000$ & $0 \cdot 058$ \\
\hline Two years after & $0 \cdot 101^{* * *}$ & $0 \cdot 013$ & $7 \cdot 920$ & $0 \cdot 000$ & $0 \cdot 127$ \\
\hline \multicolumn{6}{|c|}{ Real wage } \\
\hline & Coefficient & Std. Err & $z$ & $\mathrm{P}>|z|$ & $95 \%$ Conf. Interval \\
\hline Acquisition year & $-0 \cdot 016^{*}$ & $0 \cdot 009$ & $-1 \cdot 720$ & $0 \cdot 085$ & $-0 \cdot 034$ \\
\hline One year after & $-0 \cdot 029^{* *}$ & $0 \cdot 012$ & $-2 \cdot 410$ & $0 \cdot 016$ & -0.052 \\
\hline Two years after & $-0 \cdot 016$ & $0 \cdot 015$ & $-1 \cdot 090$ & $0 \cdot 275$ & $-0 \cdot 045$ \\
\hline \multicolumn{6}{|c|}{ Real profit } \\
\hline & Coefficient & Std. Err & $z$ & $\mathrm{P}>|z|$ & $95 \%$ Conf. Interval \\
\hline Acquisition year & $0 \cdot 127^{* * *}$ & $0 \cdot 023$ & $5 \cdot 410$ & $0 \cdot 000$ & $0 \cdot 081$ \\
\hline One year after & $0 \cdot 194^{* * *}$ & $0 \cdot 035$ & $5 \cdot 590$ & $0 \cdot 000$ & $0 \cdot 263$ \\
\hline Two years after & $0 \cdot 296^{* * *}$ & $0 \cdot 044$ & $6 \cdot 760$ & $0 \cdot 000$ & $0 \cdot 210$ \\
\hline
\end{tabular}

\section{Real Capital per worker}

\begin{tabular}{l|cccc|cc}
\hline & Coefficient & Std. Err & $z$ & $\mathrm{P}>|z|$ & $95 \%$ Conf. Interval \\
\hline Acquisition year & 0.005 & 0.012 & $0 \cdot 430$ & $0 \cdot 668$ & $-0 \cdot 018$ & $0 \cdot 028$ \\
One year after & $0.037^{* *}$ & 0.016 & $2 \cdot 410$ & $0 \cdot 016$ & $0 \cdot 007$ & $0 \cdot 068$ \\
Two years after & $0.103^{* * *}$ & 0.019 & $5 \cdot 400$ & $0 \cdot 000$ & $0 \cdot 065$ & $0 \cdot 140$ \\
\hline \hline
\end{tabular}

- This table reports the performance of domestic-acquired firms relative to nonacquisition domestic firms. All measures of firm performance are in logarithms.

- The treatment group includes domestic-acquired firms and the control group includes non-acquisition domestic firms that are paired with domestic-acquired firms using the propensity score matching method.

$-^{*},{ }^{* *}$ and ${ }^{* * *}$ denote significance at the $10 \%, 5 \%$ and $1 \%$ levels respectively. 


\section{References}

[1] Abadie, Alberto and Guido W. Imbens, 2008. "On the Failure of the Bootstrap for Matching Estimators," Econometrica, 76(6), 1537-1557.

[2] Abadie, Alberto and Guido. W. Imbens, 2009. "Matching on the Estimated Propensity Score," NBER Working Paper no. 15301.

[3] Ackerberg, Daniel A., Kevin Caves and Garth Frazer, 2006. "Structural Identification of Production Functions," Working Paper.

[4] Aguiar, Mark and Gita Gopinath, 2005. "Fire-sale Foreign Direct Investment and Liquidity Crisis," Review of Economics and Statistics, 87(3): 439-452.

[5] Ahn, S., D.J. Denis and D.K. Denis, 2006. "Leverage and Investment in Diversified Firms," Journal of Financial Economics, 79: 317-337.

[6] Aitken, Brian J. and Ann E. Harrison, 1999. "Do Domestic Firms Benefit from Direct Foreign Investment? Evidence from Venezuela," American Economic Review, 89(3): 605-618.

[7] Alfaro, Laura, Areendam Chanda, Sebnem Kalemli-Ozcan and Selin Sayek, 2004. "FDI and Economic Growth: The Role of Local Financial Markets," Journal of International Economics, 64: 89-112.

[8] Arnold, Jens M. and Beata S. Javorcik, 2009. "Gifted Kids or Pushy Parents? Foreign Acquisitions and Plant Performance in Indonesia," Journal of International Economics, 79: 42-53.

[9] Blonigen, Bruce A., Lionel Fontagné, Nicholas Sly, and Farid Toubal, forthcoming. "Cherries for Sale: The Incidence and Timing of Cross-Border M\&A," Journal of International Economics.

[10] Brandt, Loren, Johannes Van Biesebroeck and Yifan Zhang, 2012. "Creative Accounting or Creative Destruction? Firm-level Productivity Growth in Chinese Manufacturing," Journal of Development Economics, 97: 339-351.

[11] Campello, Murillo, 2006. "Debt Financing: Does It Boost or Hurt Firm Performance in Product Markets?" Journal of Financial Economics, 82: 135-172.

[12] Chen, Wenjie, 2011. "The Effect of Investor Origin on Firm Performance: Domestic and Foreign Investment in the United States," Journal of International Economics, 83(2): 219-28.

[13] De Loecker, Jan and Frederic Warzynski, 2012. "Markups and Firm-Level Export Status," American Economic Review, 102(6): 2437-2471.

[14] Dollar, David, and Shang-Jin Wei, 2007. "Das (Wasted) Kapital: Firm Ownership and Investment Efficiency in China," National Bureau of Economic Research Working Paper 13103.

[15] Fons-Rosen, Christian, Sebnem Kalemli-Ozcan, Bent E. Sorensen, Carolina Villegas-Sanchez and Vadym Volosovych, 2013. "Quantifying Productivity Gains from Foreign Investment," NBER Working Paper 18920. 
[16] Fons-Rosen, Christian, Sebnem Kalemli-Ozcan, Bent E. Sorensen, Carolina Villegas-Sanchez and Vadym Volosovych, 2014. "Foreign Ownership, Selection, and Productivity," Working Paper.

[17] Fresard, Laurent, 2010. "Financial Strength and Product Market Behavior: The Real Effects of Corporate Cash Holdings," Journal of Finance, 65: 1097-1122.

[18] Fukao, Kyoji, Keiko Ito, Hyeog Ug Kwon and Miho Takizawa, 2008. "Cross-Border Acquisitions and Target Firms' Performance Evidence from Japanese Firm-Level Data," in: Takatoshi Ito and Andrew K. Rose (Eds.) International Financial Issues in the Pacific Rim: Global Imbalances, Financial Liberalization, and Exchange Rate Policy (NBER-EASE Volume 17), 347-389.

[19] Gamba, Andrea and Alexander Triantis, 2008. "The Value of Financial Flexibility," Journal of Finance, 63: 2263-2296.

[20] Girma, Sourafel and Holger Görg, 2007. "Evaluating the Foreign Ownership Wage Premium Using a Difference-in-differences Matching Approach," Journal of International Economics, 72: $97-112$.

[21] Girma, Sourafel, Yundan Gong, Holger Görg and Sandra Lancheros, 2012. "Foreign Ownership Structure, Technology Upgrading and Exports: Evidence from Chinese Firms," Kiel Working Paper No. 1793.

[22] Greenaway, David, Alessandra Guariglia, and Richard Kneller, 2007. "Financial Factors and Exporting Decisions," Journal of International Economics, 73: 377-395.

[23] Guadalupe, Maria, Olga Kuzmina and Catherine Thomas, 2012. "Innovation and Foreign Ownership," American Economic Review, 102(7): 3594-3627.

[24] Harrison, Ann E. and Margaret S. McMillan, 2003. "Does Direct Foreign Investment Affect Domestic Credit Constraints?" Journal of International Economics, 61: 73-100.

[25] Huang, Yasheng, Li Jin and Yi Qian, 2013. "Does Ethnicity Pay? Evidence from Oversees Chinese FDI in China," Review of Economics and Statistics, 95(3): 868-883.

[26] Huang, Yasheng, Yue Ma, Zhi Yang and Yifan Zhang, 2008. "A Fire Sale without Fire: An Explanation of Labor Intensive FDI in China," MIT Sloan Research Paper No. 4713-08.

[27] Javorcik, Beata Smarzynska, 2004. "Does Foreign Direct Investment Increase the Productivity of Domestic Firms? In Search of Spillovers Through Backward Linkages," American Economic Review, 94(3): 605-627.

[28] Javorcik, Beata Smarzynska and Mariana Spatareanu, 2008. "To Share or Not to Share: Does Local Participation Matter for Spillovers from Foreign Direct Investment?" Journal of Development Economics, 85: 194-217.

[29] Ju, Jiandong, Shu Lin and Shang-Jin Wei, 2014. "Evidence on the Credit Channel of Monetary Policy:Solving Causality by Using the Impossible Trinity," manuscript, Tsinghua University, Fudan University and Columbia University. 
[30] Kamal, Fariha, 2014. "Origin of Foreign Direct Investment and Firm Performance: Evidence from Foreign Acquisitions of Chinese Domestic Firms," The World Economy, doi: $10.1111 /$ twec.12147.

[31] Keller, Wolfgang and Stephen Yeaple, 2009. "Multinational Enterprises, International Trade, and Productivity Growth: Firm Level Evidence from the United States," Review of Economics and Statistics, 91(4): 821-831.

[32] Krugman, Paul, 2001. "Fire-sale FDI," in Sebastian Edwards (ed.), Capital Flows and the Emerging Economies: Theory, Evidence and Controversies, Chicago: University of Chicago Press, 43-60.

[33] Lechner, Michael, 2002. "Program Heterogeneity and Propensity Score Matching: An Application to the Evaluation of Active Labor Market Policies," Review of Economics and Statistics, 84: $205-220$.

[34] Ma, Yue, Heiwai Tang and Yifan Zhang, 2014. "Factor Intensity, Product Switching, and Productivity: Evidence from Chinese Exporters," Journal of International Economics, 92(2): 349-362.

[35] Maksimovic, Vojislov and Gordon Phillips, 2001. "The Market for Corporate Assets: Who Engages in Mergers and Asset Sales and Are There Efficiency Gains?" Journal of Finance, LVI(6): 2019-2065.

[36] Manova, Kalina, Shang-Jin Wei and Zhiwei Zhang, forthcoming. "Firm Exports and Multinational Activity under Credit Constraints," Review of Economics and Statistics.

[37] Manova, Kalina and Zhiwei Zhang, 2009. "China's Exporters and Importers: Firms, Products and Trade Partners," NBER Working Paper No.15249.

[38] Manova, Kalina and Zhihong Yu, 2011. "Firms and Credit Constraints along the Global Value Chain: Processing Trade in China," NBER working paper no. 18561.

[39] Nocke, Volker and Stephen Yeaple, 2007. "Cross-border Mergers and Acquisitions vs. Greenfield Foreign Direct Investment: The Role of Firm Heterogeneity," Journal of International Economics, 72: 336-365

[40] Nocke, Volker and Stephen Yeaple, 2008. "An Assignment Theory of Foreign Direct Investment," Review of Economic Studies, 75: 529-557.

[41] Song, Zheng, Kjetil Storesletten and Fabrizio Zilibotti, 2011. "Growing like China," American Economic Review, 101: 202-241.

[42] Yasar, Mahmut and Catherine J. Morrison Paul, 2007. "International Linkages and Productivity at the Plant Level: Foreign Direct Investment, Exports, Imports and Licensing," Journal of International Economics, 71: 373-388.

[43] Yu, Miaojie, forthcoming. "Processing Trade, Firm Productivity, and Tariff Reductions: Evidence from Chinese Products," Economic Journal. 


\section{Appendix}

\section{A.1 Registration Types of Chinese Firms}

Table A.1 shows the registration types of Chinese firms. We divide the registration types into four categories: 1) state or collectively owned domestic firms; 2) privately owned domestic firms; 3) mixed domestic firms; and 4) FDI firms.

Table A.1: Registration Types of Chinese Firms

\begin{tabular}{c|c}
\hline \hline Registration code & Registration type \\
\hline 100 & Domestic enterprise \\
110 & State-owned enterprise \\
120 & Collectively owned enterprise \\
130 & Joint-stock cooperative enterprise \\
140 & Jointly operated enterprise \\
141 & State-owned jointly operated enterprise \\
142 & Collectively owned jointly operated enterprise \\
143 & State and collectively owned jointly operated enterprise \\
149 & Other jointly operated enterprise \\
150 & Limited liability cooperation (LLC) \\
151 & State-owned LLC \\
159 & Other LLC \\
160 & Stock limited company \\
170 & Privately owned enterprises \\
171 & Sole proprietorship \\
172 & Partnership \\
173 & Private limited liability corporations \\
174 & Private company limited by shares \\
190 & Other domestic enterprise \\
\hline 200 & Hong Kong, Macau and Taiwan (HMT) investment enterprise \\
210 & Jointly owned enterprise \\
220 & Jointly operated enterprise \\
230 & HMT solely owned enterprise \\
240 & HMT investment LLC \\
300 & Foreign investment enterprise \\
310 & Jointly owned enterprise \\
320 & Jointly operated enterprise \\
330 & Foreign owned enterprise \\
340 & investment LLC \\
\hline \hline
\end{tabular}

- This table shows the registration types of Chinese firms that are obtained from the National Bureau of Statistics of the People's Republic of China.

The state or collectively owned domestic firms category includes the following registration types: 110, 120, 141, 142, 143 and 151. The privately owned domestic firms category includes all types 
under 170 (from 171 to 174). The mixed domestic firms category includes all other registration types falling under domestic enterprises (100). The FDI firms category includes all registration types falling under Hong Kong, Macau and Taiwan (HMT) investment enterprise (200) and foreign investment enterprise (300).

If a firm's registration type changed from one category to another, its main ownership must have changed due to mergers and acquisitions. Firms are classified as domestic acquired if their registration type changed within the first three categories, while firms are classified as foreign acquired if their registration type changed from one of the three domestic categories into the category of FDI firms. As mentioned in the paper, this method fails to capture acquisitions within a category.

\section{A.2 Simple OLS Regressions}

This section describes the simple OLS regressions whose results are reported in the beginning of section 4 as the first pass of our difference-in-differences empirical exercises.

We use the following equation for our simple OLS regressions:

$$
y_{i}=\alpha+\beta W_{i}+\gamma X_{i}+\varepsilon_{i}
$$

where $y_{i}$ is firm $i$ 's change of performance following the acquisition, $W_{i}$ is a dummy variable indicating foreign acquisitions (vs. domestic acquisitions) and $X_{i}$ includes variables that are used to control for pre-acquisition differences among firms. In particular, $X_{i}$ are independent variables in our logit model (see section 3.1 for a description of these variables) and a dummy variable for provinces of firm location. We consider six regressions and use changes in three measures of productivity, the leverage ratio, the liquidity ratio and export share as our dependent variable respectively in each of these six regressions. Regression results are reported in the following tables. To save space, we only report the results for one of the three measures of productivity (TFP). In each table, the row of Treated is for the estimation results of $\beta$ in equation (A.0.1). K/L is real capital per worker, and other variables should be self-explanatory. 
Table A.2: OLS Regression Results for Productivity

\begin{tabular}{l|ccc|ccc|ccc}
\hline \hline & \multicolumn{3}{|c|}{ Acquisition year } & \multicolumn{3}{c|}{ One year after } & \multicolumn{3}{c}{ Two years after } \\
\hline & Coeff. & Std. Err & $\mathrm{P}>|z|$ & Coeff. & Std. Err & $\mathrm{P}>|z|$ & Coeff. & Std. Err & $\mathrm{P}>|z|$ \\
\hline Treated & $0 \cdot 021$ & $0 \cdot 017$ & $0 \cdot 231$ & $-0 \cdot 009$ & $0 \cdot 021$ & $0 \cdot 673$ & $0 \cdot 043^{*}$ & $0 \cdot 026$ & $0 \cdot 098$ \\
Employment & $0 \cdot 025^{* * *}$ & $0 \cdot 005$ & $0 \cdot 000$ & $0 \cdot 017^{*}$ & $0 \cdot 009$ & $0 \cdot 050$ & $0 \cdot 020^{* *}$ & $0 \cdot 010$ & $0 \cdot 039$ \\
Real wage & $-0 \cdot 141^{* * *}$ & $0 \cdot 011$ & $0 \cdot 000$ & $-0 \cdot 160^{* * *}$ & $0 \cdot 013$ & $0 \cdot 000$ & $-0 \cdot 174^{* * *}$ & $0 \cdot 017$ & $0 \cdot 000$ \\
Age & $-0 \cdot 002^{* * *}$ & $0 \cdot 000$ & $0 \cdot 000$ & $-0 \cdot 001^{* *}$ & $0 \cdot 001$ & $0 \cdot 017$ & $-0 \cdot 002^{* *}$ & $0 \cdot 001$ & $0 \cdot 033$ \\
K/L & $0 \cdot 032^{* * *}$ & $0 \cdot 006$ & $0 \cdot 000$ & $0 \cdot 034^{* * *}$ & $0 \cdot 008$ & $0 \cdot 000$ & $0 \cdot 036^{* * *}$ & $0 \cdot 009$ & $0 \cdot 000$ \\
Export & $-0 \cdot 023^{* *}$ & $0 \cdot 011$ & $0 \cdot 034$ & $-0 \cdot 012$ & $0 \cdot 017$ & $0 \cdot 499$ & $-0 \cdot 010$ & $0 \cdot 022$ & $0 \cdot 663$ \\
Leverage & $-0 \cdot 095^{* * *}$ & $0 \cdot 027$ & $0 \cdot 001$ & $-0 \cdot 162^{* * *}$ & $0 \cdot 039$ & $0 \cdot 000$ & $-0 \cdot 204^{* * *}$ & $0 \cdot 051$ & $0 \cdot 000$ \\
Liquidity & $-0 \cdot 079^{* * *}$ & $0 \cdot 027$ & $0 \cdot 003$ & $-0 \cdot 168^{* * *}$ & $0 \cdot 038$ & $0 \cdot 000$ & $-0 \cdot 274^{* * *}$ & $0 \cdot 044$ & $0 \cdot 000$ \\
State-owned & $-0 \cdot 016$ & $0 \cdot 011$ & $0 \cdot 137$ & $-0 \cdot 039^{* * *}$ & $0 \cdot 014$ & $0 \cdot 007$ & $-0 \cdot 060^{* * *}$ & $0 \cdot 018$ & $0 \cdot 001$ \\
\hline \hline
\end{tabular}

- The dependent variable is the change in productivity (as measured by firm-level TFP) following acquisitions.

- Treated is for the estimate of $\beta$ in equation (A.0.1).

- K/L is the real capital per worker, Export is the export status, Leverage is the leverage ratio, Liquidity is the liquidity ratio and State-owned is a dummy for state/collectively owned enterprises. See Section 3 for a description of these variables.

- Other independent variables that are not reported in the table include industry, year and location dummies.

$-^{*},{ }^{* *}$ and ${ }^{* * *}$ denote significance at the $10 \%, 5 \%$ and $1 \%$ levels respectively.

Table A.3: OLS Regression Results for the Leverage Ratio

\begin{tabular}{l|ccc|ccc|ccc}
\hline \hline & \multicolumn{3}{|c|}{ Acquisition year } & \multicolumn{3}{c|}{ One year after } & \multicolumn{3}{c}{ Two years after } \\
\hline & Coeff. & Std. Err & $\mathrm{P}>|z|$ & Coeff. & Std. Err & $\mathrm{P}>|z|$ & Coeff. & Std. Err & $\mathrm{P}>|z|$ \\
\hline Treated & $-0 \cdot 019^{* * *}$ & $0 \cdot 003$ & $0 \cdot 000$ & $-0 \cdot 021^{* * *}$ & $0 \cdot 005$ & $0 \cdot 000$ & $-0 \cdot 015^{* *}$ & $0 \cdot 006$ & $0 \cdot 019$ \\
Employment & $0 \cdot 006^{* * *}$ & $0 \cdot 001$ & $0 \cdot 000$ & $0 \cdot 010^{* * *}$ & $0 \cdot 001$ & $0 \cdot 000$ & $0 \cdot 010^{* * *}$ & $0 \cdot 002$ & $0 \cdot 000$ \\
Real wage & $0 \cdot 001$ & $0 \cdot 002$ & $0 \cdot 529$ & $-0 \cdot 002$ & $0 \cdot 003$ & $0 \cdot 335$ & $0 \cdot 000$ & $0 \cdot 003$ & $0 \cdot 992$ \\
Age & $0 \cdot 000^{* * *}$ & $0 \cdot 000$ & $0 \cdot 000$ & $0 \cdot 000^{* * *}$ & $0 \cdot 000$ & $0 \cdot 006$ & $0 \cdot 000^{* *}$ & $0 \cdot 000$ & $0 \cdot 038$ \\
K/L & $-0 \cdot 002$ & $0 \cdot 001$ & $0 \cdot 130$ & $-0 \cdot 002$ & $0 \cdot 002$ & $0 \cdot 329$ & $-0 \cdot 003$ & $0 \cdot 002$ & $0 \cdot 125$ \\
Export & $0 \cdot 001$ & $0 \cdot 003$ & $0 \cdot 639$ & $0 \cdot 001$ & $0 \cdot 004$ & $0 \cdot 794$ & $0 \cdot 005$ & $0 \cdot 005$ & $0 \cdot 290$ \\
Leverage & $-0 \cdot 309^{* * *}$ & $0 \cdot 009$ & $0 \cdot 000$ & $-0 \cdot 406^{* * *}$ & $0 \cdot 010$ & $0 \cdot 000$ & $-0 \cdot 492^{* * *}$ & $0 \cdot 013$ & $0 \cdot 000$ \\
Liquidity & $-0 \cdot 008$ & $0 \cdot 006$ & $0 \cdot 157$ & $-0 \cdot 012$ & $0 \cdot 008$ & $0 \cdot 137$ & $-0 \cdot 036^{* * *}$ & $0 \cdot 012$ & $0 \cdot 003$ \\
State-owned & $-0 \cdot 009^{* * *}$ & $0 \cdot 003$ & $0 \cdot 000$ & $-0 \cdot 005$ & $0 \cdot 004$ & $0 \cdot 182$ & $-0 \cdot 004$ & $0 \cdot 005$ & $0 \cdot 409$ \\
\hline \hline
\end{tabular}

- The dependent variable is the change in the leverage ratio following acquisitions.

- Treated is for the estimate of $\beta$ in equation (A.0.1).

- K/L is the real capital per worker, Export is the export status, Leverage is the leverage ratio, Liquidity is the liquidity ratio and State-owned is a dummy for state/collectively owned enterprises. See Section 3 for a description of these variables.

- Other independent variables that are not reported in the table include industry, year and location dummies. $-^{*},{ }^{* *}$ and ${ }^{* * *}$ denote significance at the $10 \%, 5 \%$ and $1 \%$ levels respectively. 
Table A.4: OLS Regression Results for the Liquidity Ratio

\begin{tabular}{l|ccc|ccc|ccc}
\hline \hline & \multicolumn{3}{|c|}{ Acquisition year } & \multicolumn{3}{c|}{ One year after } & \multicolumn{3}{c}{ Two years after } \\
\hline & Coeff. & Std. Err & $\mathrm{P}>|z|$ & Coeff. & Std. Err & $\mathrm{P}>|z|$ & Coeff. & Std. Err & $\mathrm{P}>|z|$ \\
\hline Treated & $0 \cdot 029^{* * *}$ & $0 \cdot 005$ & $0 \cdot 000$ & $0 \cdot 036^{* * *}$ & $0 \cdot 007$ & $0 \cdot 000$ & $0 \cdot 036^{* * *}$ & $0 \cdot 009$ & $0 \cdot 000$ \\
Employment & $-0 \cdot 013^{* * *}$ & $0 \cdot 001$ & $0 \cdot 000$ & $-0 \cdot 018^{* * *}$ & $0 \cdot 002$ & $0 \cdot 000$ & $-0 \cdot 019^{* * *}$ & $0 \cdot 002$ & $0 \cdot 000$ \\
Real wage & $0 \cdot 016^{* * *}$ & $0 \cdot 002$ & $0 \cdot 000$ & $0 \cdot 019^{* * *}$ & $0 \cdot 003$ & $0 \cdot 000$ & $0 \cdot 019^{* * *}$ & $0 \cdot 004$ & $0 \cdot 000$ \\
Age & $-0 \cdot 001^{* * *}$ & $0 \cdot 000$ & $0 \cdot 000$ & $0 \cdot 000^{* * *}$ & $0 \cdot 000$ & $0 \cdot 006$ & $0 \cdot 000$ & $0 \cdot 000$ & $0 \cdot 337$ \\
K/L & $-0 \cdot 013^{* * *}$ & $0 \cdot 001$ & $0 \cdot 000$ & $-0 \cdot 011^{* * *}$ & $0 \cdot 002$ & $0 \cdot 000$ & $-0 \cdot 012^{* * *}$ & $0 \cdot 003$ & $0 \cdot 000$ \\
Export & $-0 \cdot 001$ & $0 \cdot 004$ & $0 \cdot 720$ & $-0 \cdot 006$ & $0 \cdot 005$ & $0 \cdot 241$ & $-0 \cdot 003$ & $0 \cdot 007$ & $0 \cdot 608$ \\
Leverage & $-0 \cdot 094^{* * *}$ & $0 \cdot 009$ & $0 \cdot 000$ & $-0 \cdot 113^{* * *}$ & $0 \cdot 012$ & $0 \cdot 000$ & $-0 \cdot 108^{* * *}$ & $0 \cdot 015$ & $0 \cdot 000$ \\
Liquidity & $-0 \cdot 412^{* * *}$ & $0 \cdot 010$ & $0 \cdot 000$ & $-0 \cdot 492^{* * *}$ & $0 \cdot 013$ & $0 \cdot 000$ & $-0 \cdot 548^{* * *}$ & $0 \cdot 017$ & $0 \cdot 000$ \\
State-owned & $0 \cdot 008^{* * *}$ & $0 \cdot 003$ & $0 \cdot 004$ & $0 \cdot 003$ & $0 \cdot 004$ & 0.533 & $-0 \cdot 001$ & $0 \cdot 006$ & 0.919 \\
\hline \hline
\end{tabular}

- The dependent variable is the change in the liquidity ratio following acquisitions.

- Treated is for the estimate of $\beta$ in equation (A.0.1).

- K/L is the real capital per worker, Export is the export status, Leverage is the leverage ratio, Liquidity is the liquidity ratio and State-owned is a dummy for state/collectively owned enterprises. See Section 3 for a description of these variables.

- Other independent variables that are not reported in the table include industry, year and location dummies.

$-^{*},{ }^{* *}$ and ${ }^{* * *}$ denote significance at the $10 \%, 5 \%$ and $1 \%$ levels respectively.

Table A.5: OLS Regression Results for the Export Share

\begin{tabular}{l|ccc|ccc|ccc}
\hline \hline & \multicolumn{3}{|c|}{ Acquisition year } & \multicolumn{3}{c|}{ One year after } & \multicolumn{3}{c}{ Two years after } \\
\hline & Coeff. & Std. Err & $\mathrm{P}>|z|$ & Coeff. & Std. Err & $\mathrm{P}>|z|$ & Coeff. & Std. Err & $\mathrm{P}>|z|$ \\
\hline Treated & $0 \cdot 027^{* * *}$ & $0 \cdot 005$ & $0 \cdot 000$ & $0 \cdot 032^{* * *}$ & $0 \cdot 005$ & $0 \cdot 000$ & $0 \cdot 028^{* * *}$ & $0 \cdot 008$ & $0 \cdot 000$ \\
Employment & $0 \cdot 007^{* * *}$ & $0 \cdot 001$ & $0 \cdot 000$ & $0 \cdot 009^{* * *}$ & $0 \cdot 001$ & $0 \cdot 000$ & $0 \cdot 014^{* * *}$ & $0 \cdot 002$ & $0 \cdot 000$ \\
Real wage & $0 \cdot 006^{* * *}$ & $0 \cdot 002$ & $0 \cdot 000$ & $0 \cdot 008^{* * *}$ & $0 \cdot 002$ & $0 \cdot 000$ & $0 \cdot 007^{* *}$ & $0 \cdot 003$ & $0 \cdot 012$ \\
Age & $0 \cdot 000$ & $0 \cdot 000$ & $0 \cdot 845$ & $0 \cdot 000$ & $0 \cdot 000$ & $0 \cdot 924$ & $0 \cdot 000$ & $0 \cdot 000$ & $0 \cdot 118$ \\
K/L & $0 \cdot 001$ & $0 \cdot 001$ & $0 \cdot 382$ & $0 \cdot 000$ & $0 \cdot 001$ & $0 \cdot 946$ & $0 \cdot 002$ & $0 \cdot 002$ & $0 \cdot 157$ \\
Export & $-0 \cdot 087^{* * *}$ & $0 \cdot 006$ & $0 \cdot 000$ & $-0 \cdot 098^{* * *}$ & $0 \cdot 007$ & $0 \cdot 000$ & $-0 \cdot 116^{* * *}$ & $0 \cdot 010$ & $0 \cdot 000$ \\
Leverage & $0 \cdot 004$ & $0 \cdot 005$ & $0 \cdot 426$ & $-0 \cdot 006$ & $0 \cdot 007$ & $0 \cdot 376$ & $-0 \cdot 001$ & $0 \cdot 010$ & $0 \cdot 958$ \\
Liquidity & $-0 \cdot 001$ & $0 \cdot 004$ & $0 \cdot 811$ & $-0 \cdot 004$ & $0 \cdot 007$ & $0 \cdot 579$ & $0 \cdot 008$ & $0 \cdot 010$ & $0 \cdot 414$ \\
state-owned & $-0 \cdot 001$ & $0 \cdot 002$ & $0 \cdot 604$ & $0 \cdot 000$ & $0 \cdot 003$ & $0 \cdot 925$ & $0 \cdot 001$ & $0 \cdot 004$ & $0 \cdot 731$ \\
\hline \hline
\end{tabular}

- The dependent variable is the change in export share following acquisitions.

- Treated is for the estimate of $\beta$ in equation (A.0.1).

- K/L is the real capital per worker, Export is the export status, Leverage is the leverage ratio, Liquidity is the liquidity ratio and State-owned is a dummy for state/collectively owned enterprises. See Section 3 for a description of these variables.

- Other independent variables that are not reported in the table include industry, year and location dummies. $-^{*},{ }^{* *}$ and ${ }^{* * *}$ denote significance at the $10 \%, 5 \%$ and $1 \%$ levels respectively. 


\section{A.3 Robustness Checks}

\section{All Registration Type Changes as Indicators of Acquisitions}

Table A.6: Results for All Registration Type Changes

\begin{tabular}{|c|c|c|c|c|c|c|}
\hline \multicolumn{7}{|c|}{ Productivity (as measured by TFP) } \\
\hline & Coefficient & Std. Err & $z$ & $\mathrm{P}>|z|$ & $95 \%$ Conf & Interval \\
\hline Acquisition year & $0 \cdot 028$ & $0 \cdot 024$ & $1 \cdot 170$ & $0 \cdot 244$ & $-0 \cdot 019$ & $0 \cdot 076$ \\
\hline One year after & $0 \cdot 030$ & $0 \cdot 032$ & $0 \cdot 910$ & $0 \cdot 361$ & $-0 \cdot 034$ & $0 \cdot 093$ \\
\hline Two years after & $0 \cdot 025$ & $0 \cdot 034$ & $0 \cdot 740$ & $0 \cdot 462$ & $-0 \cdot 042$ & $0 \cdot 092$ \\
\hline \multicolumn{7}{|c|}{ Leverage ratio } \\
\hline & Coefficient & Std. Err & $z$ & $\mathrm{P}>|z|$ & $95 \%$ Conf & Interval \\
\hline Acquisition year & $-0 \cdot 021^{* * *}$ & $0 \cdot 006$ & $-3 \cdot 200$ & $0 \cdot 001$ & $-0 \cdot 033$ & $-0 \cdot 008$ \\
\hline One year after & $-0 \cdot 019^{* * *}$ & $0 \cdot 007$ & $-2 \cdot 690$ & $0 \cdot 007$ & $-0 \cdot 033$ & $-0 \cdot 005$ \\
\hline Two years after & $-0 \cdot 014^{*}$ & $0 \cdot 009$ & $-1 \cdot 680$ & $0 \cdot 093$ & $-0 \cdot 031$ & $0 \cdot 002$ \\
\hline \multicolumn{7}{|c|}{ Liquidity ratio } \\
\hline & Coefficient & Std. Err & $z$ & $\mathrm{P}>|z|$ & $95 \%$ Conf & Interval \\
\hline Acquisition year & $0 \cdot 025^{* * *}$ & $0 \cdot 008$ & $3 \cdot 300$ & $0 \cdot 001$ & $0 \cdot 010$ & $0 \cdot 041$ \\
\hline One year after & $0 \cdot 042^{* * *}$ & $0 \cdot 009$ & $4 \cdot 760$ & $0 \cdot 000$ & $0 \cdot 025$ & $0 \cdot 059$ \\
\hline Two years after & $0 \cdot 040^{* * *}$ & $0 \cdot 012$ & $3 \cdot 490$ & $0 \cdot 000$ & $0 \cdot 018$ & $0 \cdot 063$ \\
\hline \multicolumn{7}{|c|}{ Export share } \\
\hline & Coefficient & Std. Err & $z$ & $\mathrm{P}>|z|$ & $95 \%$ Conf & Interval \\
\hline Acquisition year & $0 \cdot 029^{* * *}$ & $0 \cdot 008$ & $3 \cdot 690$ & $0 \cdot 000$ & $0 \cdot 013$ & $0 \cdot 044$ \\
\hline One year after & $0 \cdot 034^{* * *}$ & $0 \cdot 009$ & $3 \cdot 990$ & $0 \cdot 000$ & $0 \cdot 017$ & $0 \cdot 051$ \\
\hline Two years after & $0 \cdot 037^{* * *}$ & $0 \cdot 011$ & $3 \cdot 480$ & $0 \cdot 000$ & $0 \cdot 016$ & $0 \cdot 059$ \\
\hline
\end{tabular}

- This table reports the results when all changes in registration type are considered as acquisitions.

- The treatment group includes foreign-acquired firms and the control group includes domestic-acquired firms that are paired with foreign-acquired firms using the propensity score matching method.

$-^{*},{ }^{* *}$ and ${ }^{* * *}$ denote significance at the $10 \%, 5 \%$ and $1 \%$ levels respectively. 


\section{Foreign Acquisitions of Private Firms}

Table A.7: Results for Private Firms Only

\begin{tabular}{|c|c|c|c|c|c|c|}
\hline \multicolumn{7}{|c|}{ Productivity (as measured by TFP) } \\
\hline & Coefficient & Std. Err & $z$ & $\mathrm{P}>|z|$ & \multicolumn{2}{|c|}{$95 \%$ Conf. Interval } \\
\hline Acquisition Year & $0 \cdot 080^{* *}$ & $0 \cdot 034$ & $2 \cdot 401$ & $0 \cdot 016$ & $0 \cdot 015$ & $0 \cdot 146$ \\
\hline One year after & $-0 \cdot 015$ & $0 \cdot 037$ & $-0 \cdot 405$ & $0 \cdot 686$ & $-0 \cdot 087$ & $0 \cdot 057$ \\
\hline Two years after & $-0 \cdot 024$ & $0 \cdot 037$ & $-0 \cdot 647$ & 0.518 & $-0 \cdot 098$ & $0 \cdot 049$ \\
\hline \multicolumn{7}{|c|}{ Leverage ratio } \\
\hline & Coefficient & Std. Err & $z$ & $\mathrm{P}>|z|$ & \multicolumn{2}{|c|}{ 95\% Conf. Interval } \\
\hline Acquisition Year & $-0 \cdot 031^{* * *}$ & $0 \cdot 008$ & $-4 \cdot 136$ & $0 \cdot 000$ & $-0 \cdot 046$ & $-0 \cdot 016$ \\
\hline One year after & $-0 \cdot 036^{* * *}$ & $0 \cdot 009$ & $-4 \cdot 064$ & $0 \cdot 000$ & $-0 \cdot 053$ & $-0 \cdot 019$ \\
\hline Two years after & $-0 \cdot 022^{* *}$ & $0 \cdot 010$ & $-2 \cdot 278$ & $0 \cdot 023$ & $-0 \cdot 041$ & $-0 \cdot 003$ \\
\hline \multicolumn{7}{|c|}{ Liquidity ratio } \\
\hline & Coefficient & Std. Err & $z$ & $\mathrm{P}>|z|$ & \multicolumn{2}{|c|}{$95 \%$ Conf. Interval } \\
\hline Acquisition Year & $0 \cdot 043^{* * *}$ & $0 \cdot 011$ & $3 \cdot 992$ & $0 \cdot 000$ & $0 \cdot 022$ & $0 \cdot 064$ \\
\hline One year after & $0 \cdot 059^{* * *}$ & $0 \cdot 012$ & $4 \cdot 741$ & $0 \cdot 000$ & $0 \cdot 035$ & $0 \cdot 083$ \\
\hline Two years after & $0 \cdot 045^{* * *}$ & $0 \cdot 013$ & $3 \cdot 377$ & $0 \cdot 000$ & $0 \cdot 019$ & $0 \cdot 071$ \\
\hline \multicolumn{7}{|c|}{ Export share } \\
\hline & Coefficient & Std. Err & $z$ & $\mathrm{P}>|z|$ & \multicolumn{2}{|c|}{$95 \%$ Conf. Interval } \\
\hline Acquisition Year & $0 \cdot 037^{* * *}$ & $0 \cdot 010$ & $3 \cdot 544$ & $0 \cdot 000$ & $0 \cdot 016$ & $0 \cdot 057$ \\
\hline One year after & $0 \cdot 039^{* * *}$ & $0 \cdot 012$ & $3 \cdot 353$ & $0 \cdot 000$ & $0 \cdot 016$ & $0 \cdot 062$ \\
\hline Two years after & $0 \cdot 042^{* * *}$ & $0 \cdot 012$ & $3 \cdot 531$ & $0 \cdot 000$ & $0 \cdot 018$ & 0.065 \\
\hline
\end{tabular}

- This table reports the results for the firms that were privately owned before the acquisition.

- The treatment group includes foreign-acquired firms and the control group includes domestic-acquired firms that are paired with foreign-acquired firms using the propensity score matching method.

$-{ }^{*},{ }^{* *}$ and ${ }^{* * *}$ denote significance at the $10 \%, 5 \%$ and $1 \%$ levels respectively. 


\section{$\underline{\text { Different Labor Intensities }}$}

Table A.8: Results for Different Labor Intensities

\begin{tabular}{|c|c|c|c|c|c|c|c|c|c|}
\hline \multicolumn{10}{|c|}{ Productivity (as measured by TFP) } \\
\hline & \multicolumn{3}{|c|}{ High labor intensity } & \multicolumn{3}{|c|}{ Medium labor intensity } & \multicolumn{3}{|c|}{ Low labor intensity } \\
\hline & Coefficient & Std. Err & $\mathrm{P}>|z|$ & Coefficient & Std. Err & $\mathrm{P}>|z|$ & Coefficient & Std. Err & $\mathrm{P}>|z|$ \\
\hline Acquisition year & $0 \cdot 066$ & $0 \cdot 049$ & $0 \cdot 179$ & $0 \cdot 029$ & $0 \cdot 047$ & $0 \cdot 542$ & $-0 \cdot 014$ & $0 \cdot 042$ & $0 \cdot 744$ \\
\hline One year after & $0 \cdot 015$ & $0 \cdot 056$ & 0.787 & $0 \cdot 051$ & $0 \cdot 053$ & $0 \cdot 343$ & $-0.095^{*}$ & $0 \cdot 056$ & $0 \cdot 089$ \\
\hline Two years after & $0 \cdot 025$ & $0 \cdot 064$ & $0 \cdot 701$ & $0 \cdot 038$ & $0 \cdot 063$ & $0 \cdot 546$ & $-0 \cdot 104^{*}$ & $0 \cdot 063$ & $0 \cdot 099$ \\
\hline \multicolumn{10}{|c|}{ Leverage ratio } \\
\hline & \multicolumn{3}{|c|}{ High labor intensity } & \multicolumn{3}{|c|}{ Medium labor intensity } & \multicolumn{3}{|c|}{ Low labor intensity } \\
\hline & Coefficient & Std. Err & $\mathrm{P}>|z|$ & Coefficient & Std. Err & $\mathrm{P}>|z|$ & Coefficient & Std. Err & $\mathrm{P}>|z|$ \\
\hline Acquisition year & $-0 \cdot 014$ & $0 \cdot 010$ & $0 \cdot 142$ & $-0 \cdot 018$ & $0 \cdot 011$ & $0 \cdot 542$ & $-0 \cdot 029^{* * *}$ & $0 \cdot 011$ & $0 \cdot 009$ \\
\hline One year after & $-0 \cdot 032^{* *}$ & $0 \cdot 013$ & $0 \cdot 014$ & $-0 \cdot 001$ & $0 \cdot 013$ & $0 \cdot 343$ & $-0 \cdot 023^{*}$ & $0 \cdot 014$ & $0 \cdot 097$ \\
\hline Two years after & $0 \cdot 005$ & $0 \cdot 015$ & $0 \cdot 742$ & $-0 \cdot 022$ & $0 \cdot 015$ & $0 \cdot 546$ & $-0 \cdot 030^{*}$ & $0 \cdot 018$ & $0 \cdot 097$ \\
\hline \multicolumn{10}{|c|}{ Liquidity ratio } \\
\hline & \multicolumn{3}{|c|}{ High labor intensity } & \multicolumn{3}{|c|}{ Medium labor intensity } & \multicolumn{3}{|c|}{ Low labor intensity } \\
\hline & Coefficient & Std. Err & $\mathrm{P}>|z|$ & Coefficient & Std. Err & $\mathrm{P}>|z|$ & Coefficient & Std. Err & $\mathrm{P}>|z|$ \\
\hline Acquisition year & $0 \cdot 022^{*}$ & $0 \cdot 012$ & $0 \cdot 065$ & $0 \cdot 016$ & $0 \cdot 014$ & $0 \cdot 265$ & $0 \cdot 039^{* * *}$ & $0 \cdot 015$ & $0 \cdot 007$ \\
\hline One year after & $0.068^{* * *}$ & $0 \cdot 017$ & $0 \cdot 000$ & $0 \cdot 043^{* *}$ & $0 \cdot 017$ & $0 \cdot 013$ & $0 \cdot 026$ & $0 \cdot 019$ & $0 \cdot 166$ \\
\hline Two years after & $0.045^{* *}$ & $0 \cdot 019$ & $0 \cdot 021$ & $0 \cdot 024$ & $0 \cdot 014$ & $0 \cdot 095$ & $0 \cdot 062^{* * *}$ & $0 \cdot 021$ & $0 \cdot 004$ \\
\hline \multicolumn{10}{|c|}{ Export share } \\
\hline & \multicolumn{3}{|c|}{ High labor intensity } & \multicolumn{3}{|c|}{ Medium labor intensity } & \multicolumn{3}{|c|}{ Low labor intensity } \\
\hline & Coefficient & Std. Err & $\mathrm{P}>|z|$ & Coefficient & Std. Err & $\mathrm{P}>|z|$ & Coefficient & Std. Err & $\mathrm{P}>|z|$ \\
\hline Acquisition year & $0 \cdot 031^{* *}$ & $0 \cdot 015$ & $0 \cdot 036$ & $0 \cdot 008$ & $0 \cdot 013$ & $0 \cdot 548$ & $0 \cdot 037^{* * *}$ & $0 \cdot 011$ & $0 \cdot 001$ \\
\hline One year after & $0 \cdot 045^{* *}$ & $0 \cdot 018$ & $0 \cdot 011$ & $0 \cdot 034^{* *}$ & $0 \cdot 013$ & $0 \cdot 010$ & $0 \cdot 023^{* *}$ & $0 \cdot 011$ & $0 \cdot 043$ \\
\hline Two years after & $0 \cdot 051^{* *}$ & $0 \cdot 022$ & $0 \cdot 022$ & $0 \cdot 016$ & $0 \cdot 016$ & $0 \cdot 332$ & $0 \cdot 030^{* *}$ & $0 \cdot 014$ & $0 \cdot 040$ \\
\hline
\end{tabular}

- Industries (2-digit level) are divided into three groups according to their labor intensity.

- The treatment group includes foreign-acquired firms and the control group includes domestic-acquired firms that are paired with foreign-acquired firms using the propensity score matching method.

$-^{*},{ }^{* *}$ and ${ }^{* * *}$ denote significance at the $10 \%, 5 \%$ and $1 \%$ levels respectively. 


\section{Wholly Foreign-owned FDI}

Table A.9: Results for Wholly Foreign-owned FDI

\begin{tabular}{|c|c|c|c|c|c|c|}
\hline \multicolumn{7}{|c|}{ Productivity (as measured by TFP) } \\
\hline & Coefficient & Std. Err & $z$ & $\mathrm{P}>|z|$ & 95\% Conf. & Interval \\
\hline Acquisition year & $-0 \cdot 006$ & $0 \cdot 045$ & $-0 \cdot 130$ & $0 \cdot 899$ & $-0 \cdot 094$ & $0 \cdot 082$ \\
\hline One year after & $-0 \cdot 015$ & $0 \cdot 052$ & $-0 \cdot 300$ & $0 \cdot 765$ & $-0 \cdot 116$ & $0 \cdot 086$ \\
\hline Two years after & $0 \cdot 078$ & $0 \cdot 059$ & $1 \cdot 320$ & $0 \cdot 188$ & $-0 \cdot 038$ & $0 \cdot 194$ \\
\hline \multicolumn{7}{|c|}{ Leverage ratio } \\
\hline & Coefficient & Std. Err & $z$ & $\mathrm{P}>|z|$ & \multicolumn{2}{|c|}{$95 \%$ Conf. Interval } \\
\hline Acquisition year & $-0 \cdot 041^{* * *}$ & $0 \cdot 011$ & $-3 \cdot 670$ & $0 \cdot 000$ & $-0 \cdot 064$ & $-0 \cdot 019$ \\
\hline One year after & $-0.023^{*}$ & $0 \cdot 012$ & $-1 \cdot 890$ & $0 \cdot 059$ & $-0 \cdot 048$ & $0 \cdot 001$ \\
\hline Two years after & $-0.044^{* * *}$ & $0 \cdot 015$ & $-2 \cdot 900$ & $0 \cdot 004$ & $-0 \cdot 073$ & $-0 \cdot 014$ \\
\hline \multicolumn{7}{|c|}{ Liquidity ratio } \\
\hline & Coefficient & Std. Err & $z$ & $\mathrm{P}>|z|$ & 95\% Conf. & Interval \\
\hline Acquisition year & $0 \cdot 046^{* * *}$ & $0 \cdot 015$ & $3 \cdot 130$ & $0 \cdot 002$ & $0 \cdot 017$ & $0 \cdot 074$ \\
\hline One year after & $0 \cdot 045^{* *}$ & $0 \cdot 018$ & $2 \cdot 540$ & $0 \cdot 011$ & $0 \cdot 010$ & $0 \cdot 079$ \\
\hline Two years after & $0 \cdot 070^{* * *}$ & $0 \cdot 020$ & $3 \cdot 430$ & $0 \cdot 001$ & $0 \cdot 030$ & $0 \cdot 110$ \\
\hline \multicolumn{7}{|c|}{ Export share } \\
\hline & Coefficient & Std. Err & $z$ & $\mathrm{P}>|z|$ & $95 \%$ Conf. & Interval \\
\hline Acquisition year & $0 \cdot 033^{* *}$ & $0 \cdot 017$ & 1.970 & $0 \cdot 048$ & $0 \cdot 000$ & $0 \cdot 065$ \\
\hline One year after & $0 \cdot 043^{* *}$ & $0 \cdot 017$ & $2 \cdot 560$ & $0 \cdot 011$ & $0 \cdot 010$ & $0 \cdot 076$ \\
\hline Two years after & $0 \cdot 026$ & $0 \cdot 019$ & $1 \cdot 370$ & $0 \cdot 170$ & $-0 \cdot 011$ & $0 \cdot 063$ \\
\hline
\end{tabular}

- This table reports the results for wholly foreign-owned FDI firms.

- The treatment group includes foreign-acquired firms and the control group includes domestic-acquired firms that are paired with foreign-acquired firms using the propensity score matching method.

$-^{*},{ }^{* *}$ and ${ }^{* * *}$ denote significance at the $10 \%, 5 \%$ and $1 \%$ levels respectively. 


\section{Exporters and Non-exporters}

Table A.10: Results for Exporters and Non-exporters

\begin{tabular}{|c|c|c|c|c|c|c|}
\hline \multicolumn{7}{|c|}{ Productivity (as measured by TFP) } \\
\hline & \multicolumn{3}{|c|}{ Exporters } & \multicolumn{3}{|c|}{ Non-exporters } \\
\hline & Coefficient & Std. Err & $\mathrm{P}>|z|$ & Coefficient & Std. Err & $\mathrm{P}>|z|$ \\
\hline Acquisition year & $0 \cdot 026$ & $0 \cdot 041$ & 0.525 & $0 \cdot 016$ & $0 \cdot 039$ & $0 \cdot 682$ \\
\hline One year after & -0.065 & 0.064 & $0 \cdot 308$ & $-0 \cdot 059$ & $0 \cdot 049$ & $0 \cdot 227$ \\
\hline Two years after & $0 \cdot 039$ & $0 \cdot 070$ & $0 \cdot 575$ & $0 \cdot 063$ & $0 \cdot 055$ & $0 \cdot 251$ \\
\hline \multicolumn{7}{|c|}{ Leverage ratio } \\
\hline & \multicolumn{3}{|c|}{ Exporters } & \multicolumn{3}{|c|}{ Non-exporters } \\
\hline & Coefficient & Std. Err & $\mathrm{P}>|z|$ & Coefficient & Std. Err & $\mathrm{P}>|z|$ \\
\hline Acquisition year & $-0 \cdot 037^{* * *}$ & $0 \cdot 012$ & $0 \cdot 002$ & $-0 \cdot 019^{* *}$ & $0 \cdot 009$ & $0 \cdot 037$ \\
\hline One year after & $-0 \cdot 037^{* * *}$ & $0 \cdot 013$ & $0 \cdot 004$ & $-0 \cdot 015$ & $0 \cdot 012$ & $0 \cdot 205$ \\
\hline Two years after & $-0 \cdot 037^{* * *}$ & $0 \cdot 013$ & $0 \cdot 004$ & $-0 \cdot 037^{* *}$ & $0 \cdot 016$ & $0 \cdot 018$ \\
\hline
\end{tabular}

Liquidity ratio

\begin{tabular}{l|ccc|ccr}
\hline & \multicolumn{3}{|c|}{ Exporters } & \multicolumn{3}{c}{ Non-exporters } \\
\hline & Coefficient & Std. Err & $\mathrm{P}>|z|$ & Coefficient & Std. Err & $\mathrm{P}>|z|$ \\
\hline Acquisition year & $0 \cdot 060^{* * *}$ & $0 \cdot 012$ & $0 \cdot 000$ & $0 \cdot 028^{* *}$ & $0 \cdot 012$ & $0 \cdot 019$ \\
One year after & $0 \cdot 048^{* * *}$ & $0 \cdot 017$ & $0 \cdot 006$ & $0 \cdot 049^{* * *}$ & $0 \cdot 015$ & $0 \cdot 001$ \\
Two years after & $0 \cdot 075^{* * *}$ & $0 \cdot 022$ & $0 \cdot 001$ & $0 \cdot 024$ & $0 \cdot 018$ & $0 \cdot 172$ \\
\hline \hline
\end{tabular}

Export share

\begin{tabular}{l|ccc|ccc}
\hline & \multicolumn{3}{|c|}{ Exporters } & \multicolumn{3}{c}{ Non-exporters } \\
\hline & Coefficient & Std. Err & $\mathrm{P}>|z|$ & Coefficient & Std. Err & $\mathrm{P}>|z|$ \\
\hline Acquisition year & $0 \cdot 000$ & $0 \cdot 017$ & 0.989 & $0.045^{* * *}$ & $0 \cdot 009$ & 0.000 \\
One year after & $0 \cdot 011$ & 0.019 & 0.581 & $0.043^{* * *}$ & $0 \cdot 008$ & 0.000 \\
Two years after & 0.008 & 0.025 & 0.749 & $0.057^{* * *}$ & $0 \cdot 009$ & 0.000 \\
\hline \hline
\end{tabular}

Export

\begin{tabular}{l|ccc|ccc}
\hline & \multicolumn{3}{|c|}{ Exporters } & \multicolumn{3}{c}{ Non-exporters } \\
\hline & Coefficient & Std. Err & $\mathrm{P}>|z|$ & Coefficient & Std. Err & $\mathrm{P}>|z|$ \\
\hline Acquisition Year & $0 \cdot 342^{*}$ & $0 \cdot 197$ & $0 \cdot 082$ & $0 \cdot 955^{* * *}$ & $0 \cdot 132$ & $0 \cdot 000$ \\
One year after & $0 \cdot 537^{* *}$ & $0 \cdot 225$ & $0 \cdot 017$ & $0 \cdot 690^{* * *}$ & $0 \cdot 168$ & $0 \cdot 000$ \\
Two years after & $0.591^{* *}$ & $0 \cdot 274$ & $0 \cdot 031$ & $0 \cdot 913^{* * *}$ & $0 \cdot 192$ & $0 \cdot 000$ \\
\hline \hline
\end{tabular}

- If a firm exported in one or more years before acquisition, it is classified as an exporter. Otherwise, the firm is classified as a non-exporter.

- The treatment group includes foreign-acquired firms and the control group includes domestic-acquired firms that are paired with foreign-acquired firms using the propensity score matching method.

$-{ }^{*},{ }^{* *}$ and ${ }^{* * *}$ denote significance at the $10 \%, 5 \%$ and $1 \%$ levels respectively. 


\section{Processing Trade}

Table A.11: Results for Processing-trade Foreign Acquisitions

\begin{tabular}{|c|c|c|c|c|c|c|}
\hline \multicolumn{7}{|c|}{ Productivity (as measured by TFP) } \\
\hline & \multicolumn{3}{|c|}{ Processing-trade Foreign Acquisitions } & \multicolumn{3}{|c|}{ Other Foreign Acquisitions } \\
\hline & Coefficient & Std. Err & $\mathrm{P}>|z|$ & Coefficient & Std. Err & $\mathrm{P}>|z|$ \\
\hline Acquisition Year & $-0 \cdot 006$ & $0 \cdot 459$ & 0.989 & $0 \cdot 034$ & $0 \cdot 662$ & 0.959 \\
\hline One year after & $-0 \cdot 019$ & $0 \cdot 438$ & 0.966 & $0 \cdot 001$ & $0 \cdot 746$ & 0.999 \\
\hline Two years after & $0 \cdot 056$ & $0 \cdot 408$ & $0 \cdot 891$ & $-0 \cdot 017$ & $0 \cdot 748$ & $0 \cdot 981$ \\
\hline \multicolumn{7}{|c|}{ Leverage ratio } \\
\hline & \multicolumn{3}{|c|}{ Processing-trade Foreign Acquisitions } & \multicolumn{3}{|c|}{ Other Foreign Acquisitions } \\
\hline & Coefficient & Std. Err & $\mathrm{P}>|z|$ & Coefficient & Std. Err & $\mathrm{P}>|z|$ \\
\hline Acquisition Year & $-0 \cdot 030^{* * *}$ & $0 \cdot 010$ & $0 \cdot 002$ & $-0 \cdot 025^{* * *}$ & $0 \cdot 005$ & $0 \cdot 000$ \\
\hline One year after & $0 \cdot 007^{* *}$ & $0 \cdot 004$ & $0 \cdot 040$ & $-0 \cdot 013^{* * *}$ & $0 \cdot 005$ & $0 \cdot 008$ \\
\hline Two years after & $0 \cdot 003$ & 0.005 & 0.582 & $-0 \cdot 016^{* * *}$ & $0 \cdot 006$ & $0 \cdot 006$ \\
\hline \multicolumn{7}{|c|}{ Liquidity ratio } \\
\hline & \multicolumn{3}{|c|}{ Processing-trade Foreign Acquisitions } & \multicolumn{3}{|c|}{ Other Foreign Acquisitions } \\
\hline & Coefficient & Std. Err & $\mathrm{P}>|z|$ & Coefficient & Std. Err & $\mathrm{P}>|z|$ \\
\hline Acquisition Year & $0 \cdot 030^{* * *}$ & $0 \cdot 007$ & $0 \cdot 000$ & $0 \cdot 029^{* * *}$ & $0 \cdot 008$ & $0 \cdot 000$ \\
\hline One year after & $0 \cdot 058^{* * *}$ & $0 \cdot 009$ & $0 \cdot 000$ & $0 \cdot 039^{* * *}$ & $0 \cdot 008$ & $0 \cdot 000$ \\
\hline Two years after & $0 \cdot 053^{* * *}$ & $0 \cdot 008$ & $0 \cdot 000$ & $0 \cdot 034^{* * *}$ & $0 \cdot 009$ & $0 \cdot 000$ \\
\hline \multicolumn{7}{|c|}{ Export share } \\
\hline & \multicolumn{3}{|c|}{ Processing-trade Foreign Acquisitions } & \multicolumn{3}{|c|}{ Other Foreign Acquisitions } \\
\hline & Coefficient & Std. Err & $\mathrm{P}>|z|$ & Coefficient & Std. Err & $\mathrm{P}>|z|$ \\
\hline Acquisition Year & $0 \cdot 043^{* * *}$ & $0 \cdot 013$ & $0 \cdot 000$ & $0 \cdot 016^{* *}$ & $0 \cdot 007$ & $0 \cdot 025$ \\
\hline One year after & $0 \cdot 059^{* * *}$ & $0 \cdot 009$ & $0 \cdot 000$ & $0 \cdot 024^{* * *}$ & $0 \cdot 006$ & $0 \cdot 000$ \\
\hline Two years after & $0 \cdot 026^{* * *}$ & $0 \cdot 008$ & $0 \cdot 000$ & $0 \cdot 013^{*}$ & $0 \cdot 007$ & $0 \cdot 055$ \\
\hline
\end{tabular}

- Processing-trade foreign acquisitions include firms that are classified as processing-trade firms following the acquisitions.

- In processing trade, firms export all final products after they import all or part of intermediate inputs.

$-^{*},{ }^{* *}$ and ${ }^{* * *}$ denote significance at the $10 \%, 5 \%$ and $1 \%$ levels respectively. 


\section{Non-parametric Nearest Neighbor Matching}

Table A.12: Results for Non-parametric Nearest Neighbor Matching

\begin{tabular}{|c|c|c|c|c|c|c|}
\hline \multicolumn{7}{|c|}{ Productivity (as measured by TFP) } \\
\hline & Coefficient & Std. Err & $z$ & $\mathrm{P}>|z|$ & 95\% Conf & Interval \\
\hline Acquisition Year & $0 \cdot 053^{* *}$ & $0 \cdot 022$ & $2 \cdot 380$ & $0 \cdot 017$ & $0 \cdot 009$ & $0 \cdot 097$ \\
\hline One year after & $0 \cdot 034$ & $0 \cdot 029$ & $1 \cdot 170$ & $0 \cdot 243$ & -0.023 & $0 \cdot 091$ \\
\hline Two years after & $0 \cdot 039$ & $0 \cdot 032$ & $1 \cdot 210$ & $0 \cdot 226$ & $-0 \cdot 024$ & $0 \cdot 103$ \\
\hline \multicolumn{7}{|c|}{ Leverage ratio } \\
\hline & Coefficient & Std. Err & $z$ & $\mathrm{P}>|z|$ & $95 \%$ Conf & Interval \\
\hline Acquisition Year & $-0 \cdot 020^{* * *}$ & $0 \cdot 006$ & $-3 \cdot 220$ & $0 \cdot 001$ & $-0 \cdot 032$ & $-0 \cdot 008$ \\
\hline One year after & $-0 \cdot 020^{* * *}$ & $0 \cdot 008$ & $-2 \cdot 710$ & $0 \cdot 007$ & $-0 \cdot 035$ & $-0 \cdot 006$ \\
\hline Two years after & $-0 \cdot 007$ & $0 \cdot 009$ & $-0 \cdot 770$ & $0 \cdot 439$ & $-0 \cdot 025$ & $0 \cdot 011$ \\
\hline \multicolumn{7}{|c|}{ Liquidity ratio } \\
\hline & Coefficient & Std. Err & $z$ & $\mathrm{P}>|z|$ & $95 \%$ Conf & Interval \\
\hline Acquisition Year & $0 \cdot 025^{* * *}$ & $0 \cdot 007$ & 3.500 & $0 \cdot 000$ & $0 \cdot 011$ & $0 \cdot 040$ \\
\hline One year after & $0 \cdot 026^{* * *}$ & $0 \cdot 009$ & $2 \cdot 800$ & $0 \cdot 005$ & $0 \cdot 008$ & $0 \cdot 045$ \\
\hline Two years after & $0 \cdot 023^{* *}$ & $0 \cdot 011$ & $2 \cdot 210$ & $0 \cdot 027$ & $0 \cdot 003$ & $0 \cdot 044$ \\
\hline \multicolumn{7}{|c|}{ Export share } \\
\hline & Coefficient & Std. Err & $z$ & $\mathrm{P}>|z|$ & $95 \%$ Conf & Interval \\
\hline Acquisition Year & $0 \cdot 035^{* * *}$ & $0 \cdot 008$ & $4 \cdot 180$ & $0 \cdot 000$ & $0 \cdot 019$ & $0 \cdot 052$ \\
\hline One year after & $0 \cdot 030^{* * *}$ & $0 \cdot 009$ & $3 \cdot 310$ & $0 \cdot 001$ & $0 \cdot 012$ & $0 \cdot 047$ \\
\hline Two years after & $0 \cdot 022^{* *}$ & $0 \cdot 010$ & $2 \cdot 170$ & $0 \cdot 030$ & $0 \cdot 002$ & $0 \cdot 042$ \\
\hline
\end{tabular}

- This table reports the results for the non-parametric nearest neighbor matching with the exact match for acquisition year and industry.

- The treatment group includes foreign-acquired firms and the control group includes domestic-acquired firms that are paired with foreign-acquired firms using the nonparametric nearest neighbor matching in Abadie and Imbens (2006 and 2008).

$-^{*},{ }^{* *}$ and ${ }^{* * *}$ denote significance at the $10 \%, 5 \%$ and $1 \%$ levels respectively. 